\title{
Dengue Outbreak is a Global Recurrent Crisis: Review of the Literature
}

\author{
Yusha Araf ${ }^{1}$, Md. Asad Ullah ${ }^{2}$, Nairita Ahsan Faruqui ${ }^{3}$, Sadrina Afrin Mowna ${ }^{3}$, Durdana Hossain Prium ${ }^{3}$, \\ Bishajit Sarkar ${ }^{2}$
}

\begin{abstract}
${ }^{1}$ Department of Genetic Engineering and Biotechnology, School of Life Sciences, Shahjalal University of Science and Technology, Sylhet, BANGLADESH ${ }^{2}$ Department of Biotechnology and Genetic Engineering, Faculty of Biological Sciences, Jahangirnagar University, Dhaka, BANGLADESH

${ }^{3}$ Biotechnology Program, Department of Mathematics and Natural Sciences, School of Data and Sciences, BRAC University, Dhaka, BANGLADESH *Corresponding Author: email@affiliation.com
\end{abstract}

Citation: Araf Y, Ullah MA, Faruqui NA, Mowna SA, Prium DH, Sarkar B. Dengue Outbreak is a Global Recurrent Crisis: Review of the Literature. Electron J Gen Med. 2021;18(1):em267. https://doi.org/10.29333/ejgm/8948

ARTICLE INFO

Received: 19 May 2020

Accepted: 4 Aug. 2020

\begin{abstract}
Purpose: This review features a generalized overview of dengue outbreaks, dengue pathogenesis, symptoms, immune response, diagnosis methods and preventive measures which facilitates the better understanding of the global expansion and concerns relating to the disease.

Recent Findings: A recent study showed that natural killer cells of the infected person become activated soon after the infection which may help in treatment and vaccine development. A research team has also produced synthetically engineered mosquitoes that can prevent the transmission and dissemination of the dengue virus by the activation of an antibody. Furthermore, a mutation in the protein envelope of the dengue virus leads to variation in shapes, developing resistance towards the vaccine.

Summary: The increasing number of reported cases indicated the worldwide distribution of the mosquito vectors, which was further facilitated by the growth in the shipping and commerce industries. The immune system, through activation of the innate and adaptive immune responses, facilitates the recruitment of an array of leukocytes which help neutralize the virus. However, the 4 different viral serotypes increases the risk of a life-threatening secondary infection due to the varying serotypes. Apart from the laboratory standard PRNT method, several other dengue detection methods such as ELISA, RT-LAMP and several optical, microfluidic and electrochemical methods have been developed. Since Dengvaxia ${ }^{\circledR}$ (CYD-TDV) has its own set of drawbacks and limitations, several companies have been investing for the production of more potential vaccines that are currently in trial.
\end{abstract}

Keywords: Dengue Hemorrhagic Fever (DHF), Aedes Aegypti, epidemic, pathogenesis, identification, vaccine

\section{INTRODUCTION}

Dengue is one of the most rapidly spreading mosquito borne viral infections in humans leading to about 10,000 deaths annually across over 125 countries in the world [1]. The spherical enveloped dengue virus is a positive sense single stranded RNA virus. Its genome consists of about 10,200 nucleotides which codes for structural proteins (capsid (C), envelope (E), and membrane (M) proteins) and nonstructural proteins (NS1, NS2A, NS2B, NS3, NS4A, NS4B, and NS5) [2]. Dengue virus which is a member of the genus Flavivirus (family Flaviviridae) are classified into four serotypes (DEN-1, DEN-2, DEN-3 and DEN-4) [3,4]. Mosquitoes of the genus Aedes aid to transmit dengue virus from one human to another [5][6]. These mosquitoes are ubiquitous in the tropical and subtropical regions from $30^{\circ}$ north to $20^{\circ}$ south latitude. Escalation of dengue infection is associated with climatic changes which include an increase in temperature, high levels of precipitation, humidity and the pressure of vapor. [7]. All these factors along with degree of globalization, trade and travel are coherent which facilitates the transmission of dengue vectors. A large number of dengue virus infected persons remain asymptomatic without the presence of any clinical signs and symptoms. However, in symptomatic cases, initially the patients experience mild flu syndrome known as dengue fever or break bone fever accompanied with skin rash. This may later proceed to several grades of dengue hemorrhagic fever (DHF): DHF-I, DHF-II, DHF-III and DHF-IV. DHF-I and DHF-II include nonshock patients whereas DHF-III and DHF-IV include patients with dengue shock syndrome (DSS) or prolonged shock, which eventually lead to death in very critical cases [8-11]. With no treatment available, this virus presents a life-threatening health concern for people in many countries. Understanding of symptoms and prognostic factors, timely diagnosis, conventional guidelines of patient management, supportive treatments are the possible options to combat this viral disease. This article holds an integrated knowledge of dengue pathogenesis, preventive measures, epidemiology and treatment options which should augment further progresses in dengue research and help preventing dengue outbreak. 


\section{ORIGIN OF DENGUE VIRUSES}

The first emergence of this virus seems to be recorded during the $17^{\text {th }}$ century, when there were many cases which had clinical symptoms similar to that of dengue. However, the first confirmed dengue outbreaks were reported simultaneously in Asia, Africa and North America in 1779-1780 [12]. In 1951, an American physician, Benjamin Rush mentioned about the probable dengue fever which occurred in Philadelphia, United States in 1780 [13]. He named this fever as "break bone fever"term which is synonymous to the pain the patients described they endured back then [14]. Immediately after World War 2, global dengue pandemic emerged in Southeast Asia. This was due to the destruction of water systems during the war, creating many stagnant water containers which provided a suitable environment for the mosquitoes to breed. The movement of the war equipment allowed the vectors to bypass the geographic barrier very easily [15]. Due to the dispersal of the dengue virus throughout, pacific regions and the Americans experienced DHF outbreaks. Followed by World War 2, in 1975, Southeast Asia experienced DHF endemicity due to the increased degree of urbanization and the ecological setting which was just perfect for the vectors. The countries soon became hyperendemic- all 4 serotypes were present among the human- vector cycle. The second DHF epidemic began in 1980 in Asia which expanded towards India, Pakistan, Sri Lanka, Maldives as well as the People's Republic of China [16].

Dengue virus has been proved to be a major threat to the human population in the last decade and thus transmission of viruses must be considered wisely in order to prevent the reemergence of the infection.

\section{VECTORS AND HOSTS OF DENGUE VIRUSES}

Dengue, an arthropod-borne viral infection, is transmitted from one person to another via mosquito vectors of the genus Aedes. Aedes aegypti being the principal vector and Aedes albopictus, also known as "Asian tiger mosquito"-the competent vector has a limited ability to transmit dengue virus [17]. They are well adapted to the urban environment and are found both indoors and outdoors close to human abode which makes them suitable vectors for horizontal transmission of dengue virus (mosquito-human). The primary vector of dengue virus, Aedes aegypti from the tropical and subtropical regions of the world are mostly associated with the space occupied by humans for living and feeds on human blood [18]. Female Aedes aegypti requires blood before laying eggs. Moreover, Aedes albopictus which is an exophilic mosquito even prefers feeding on human blood. Therefore, their strong preference for human blood in order to support their survival makes them an ideal vector for DENV transmission [19]. The transmission of dengue virus by a vector begins as a mosquito bites an infected person, carrying dengue virus in his or her blood. The mosquito eventually gets infected and hence becomes a dengue vector which can prove to be a threat to the population since it can horizontally transmit this virus for the rest of its lifespan (two weeks to one month). Although early studies have shown no clear evidence of vertical transmission of DENV virus in Aedes mosquitoes, recent studies prove that vertical transmission of DENV virus is attainable both experimentally as well as in nature. In addition to that, some evidence affirms that Aedes albopictus are much more efficient than Aedes aegypti in terms of vertical transmission [20]. A case of vertical transmission of dengue virus was reported in Guangzhou, China. A 25 years old woman, 39 weeks pregnant was admitted in a general hospital. She experienced fever for 5 days and then gradually developed skin rash. She went into labour and delivered a girl. Results from ELISA dengue virus NS1 antigen test (Wantai, Beijing, China) and dengue virus fluorogenic quantitative PCR test (Liferiver, Shanghai, China) confirmed that both the mother and the baby suffered from dengue [21]. Another study with 54 pregnant women was carried out in French Guiana between 2012 and 2014. Peripheral blood samples from the mothers, blood specimens from the newborns as well as the placenta was tested. The samples collected at each stage of the study was then used to carry out serological examinations i.e., reverse transcription-polymerase chain reaction (RT-PCR), identification of nonstructural 1 antigen (NS1 Ag) using Platelia $^{\text {Tn }}$ Dengue NS1 Ag capture enzyme-linked immunosorbent assay (ELISA) (Bio-Rad laboratories, MarnesLa-Coquette, France), tests for specific dengue immunoglobulin using in-house antibody capture MAC-ELISA and also tests for dengue-specific IgM/IgG antibodies using Panbio capture ELISA (Panbio, Brisbane, Australia). Analysis of the serological and the molecular results suggested that vertical transmission is much more persistent if the mothers are infected at a later stage of pregnancy. Valid and appropriate tests must be carried out in order to detect vertical transmission of dengue virus [22].

This indicates that along with horizontal transmission, vertical transmission also plays an effective role in transmission of dengue virus and imposes additional challenges to control the viral transmission.

\section{PATHOGENESIS OF DENGUE VIRUS INFECTION}

\section{Entry of Virus inside Cell and Replication}

Replication along with initiation of pathogenesis of the dengue virus begins immediately after it enters into the body. Once the mosquito feeds on the blood of an infected person, the DENV infects the midgut from where it spreads and replicates in other tissues of the mosquito. It takes about 8 to 10 days and a temperature of about $25^{\circ} \mathrm{C}$ for the virus to multiply, mature, migrate and infect the salivary glands and eventually shed in the saliva [23]. While the female dengue vector bites and feeds on the blood of a healthy individual, it injects its saliva in order to prevent blood clotting of the host and facilitates feeding. Thus, infecting the individual by inoculating the virus into the dermis and epidermis as well as injecting some viruses directly into the bloodstream. It is then followed by infection in the most common cell type in the skinkeratinocyte [24]. It infects and replicates inside a specialized immune cell in the skin- Langerhans cell (a type of dendritic cell) [25]. The infection spreads to the lymph node thus activating the recruitment of leukocytes.

The replication of a flavivirus commences as it attaches to the extracellular surface receptor on the host cell (Figure 1). The virus is then taken up into the cell by endocytosis and is confined within an endosomal vacuole. Acidification of the endosome causes a change in the E-protein thus facilitating the release of the viral genome into the cytoplasm [26]. Once the viral genome is released, it is transported to the endoplasmic 


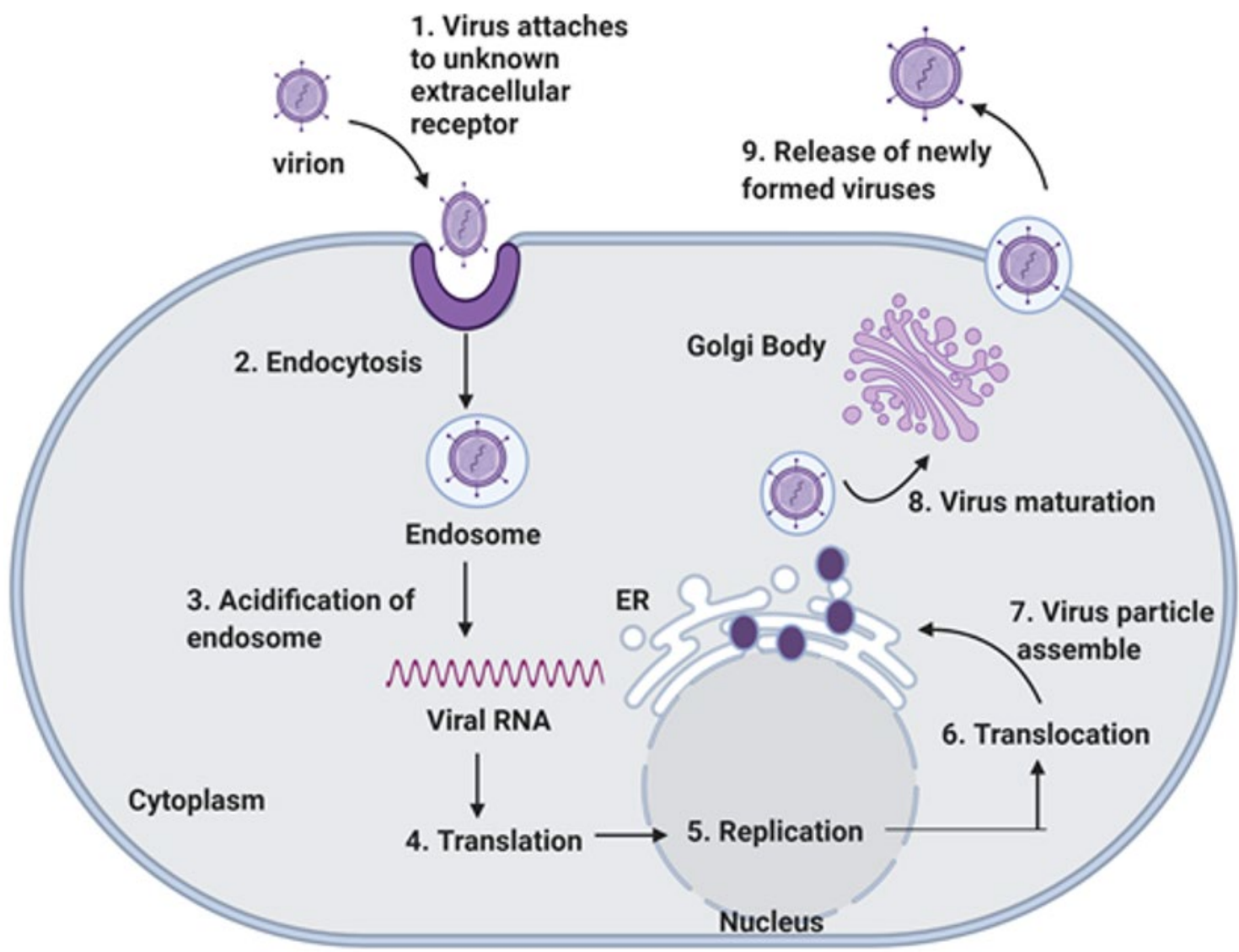

Figure 1. Reproductive Cycle of DENV virus in mediating viral pathogenesis. 1. DENV virus binds to an uncharacterized receptor on the host cell surface. 2. Enters into the cytoplasm by endocytosis. 3.Endosomal acidification causes irreversible trimerization of the viral E-protein thus exposing the viral RNA into the cytoplasm. 4. The viral RNA is translated into polyprotein in the ER. 5.After viral replication complex is synthesized, RNA synthesis starts. This takes place in two steps- positive mRNA is at first copied to negative sense mRNA and then this acts as template for synthesis of multiple stands of positive sense RNA which are then used for translation. 6.Translocation takes place. 7.Virus assembly takes place in the ER membrane. 8.Immature virus particles pass through the Golgi body where they undergo modifications. 9.Virions are released by endocytosis [28-33]. The figure was created using BioRender and exported under the terms of premium subscription.

reticulum (ER) where it undergoes two different fates: first, the genome is transcribed and translated into structural and nonstructural proteins required for virus genome replication and viral assembly; second, the genome is copied into negative sense RNA and then into multiple copies of positive sense RNAs by RNA dependent RNA polymerase (RdRp). The newly synthesized genetic materials and viral proteins are used in the new virus assembly. After making multiple copies of virions inside infected cells, they lyse the cells, get outside by endocytosis and continue to infect other healthy cells [27].

After 4 to 5 days of being bit by a dengue vector, the person develops viremia- a condition in which the level of dengue virus in blood tends to elevate due to replication of the viruses. It can last from 5 to 12 days. If a mosquito feeds on the blood of an infected individual within this time span, the mosquito becomes a dengue vector [34].

Some epidemiological studies show that the development and severity of dengue infection in humans is triggered by many factors. Age is one of them [35]. Other factors include genetic background of the host [36,37], vector, serotype of virus [38], gender, genotype [39,40], environmental condition, immune condition of the infected people, socioeconomic level of the population and secondary infection by heterologous serotype [41].

\section{Immune Response of Human Body Against Dengue Virus}

The immune system is the primary defense system of the body against dengue virus and consists of mainly two parts: The innate immune system and the adaptive immune system. While the innate immune response facilitates the immediate recognition and protection towards any invading pathogen, the adaptive immune response produces cells that specifically and efficiently target the pathogen or infected cell providing a long-term immunity [42]. The cells produced by the adaptive immune system include the antibody-secreting B cells, which are capable of recognizing and binding to foreign cells with high specificity and the cytotoxic $T$ cells which are known to attack the infected cells.

Since the keratinocytes and Langerhans cells are infected through viral replication, the Langerhans, through proper detection, display the antigens from the invading pathogens on their surfaces [43-46]. The display of the viral antigens triggers the innate immune response, summoning the white blood cells, monocytes and macrophages for the ingestion and destruction of the dengue virus. The virus infects these cells instead and spreads throughout the entire body as they travel through the lymphatic system $[46,47]$. As the virus spreads throughout, infecting cells of the bone marrow, lymph nodes, spleen, liver or blood, it facilitates the emergence of viremia. 


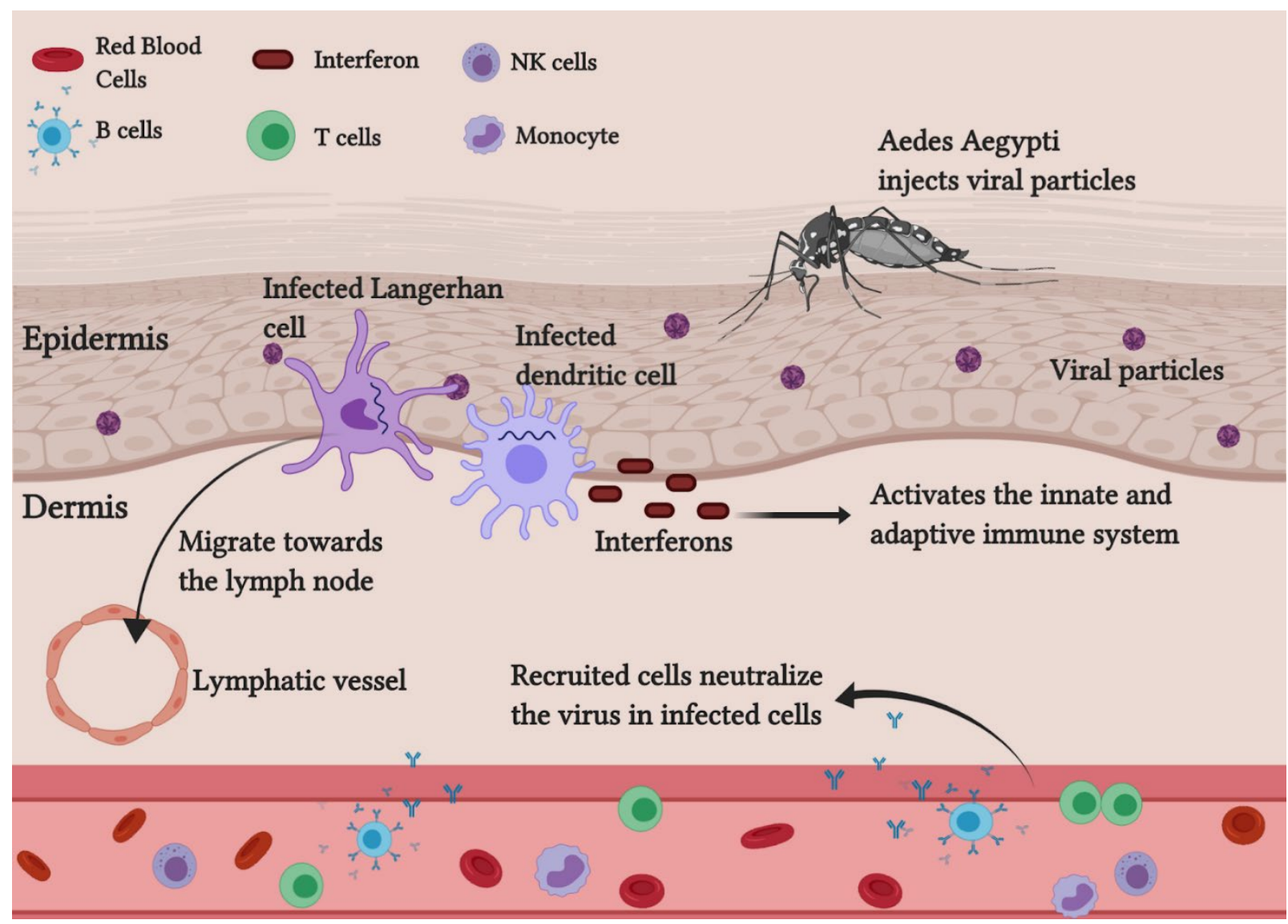

Figure 2. The immune response of the human body against dengue virus. Aedes Aegypti injects viral particles along with its saliva which infect the keratinocytes and other dendritic cells present near the skin. The infected cells represent the antigens of the pathogens on their surfaces, facilitating the recruitment of leukocytes. The infected cells migrate towards the lymph node to trigger the immune response. Soon after, more and more cells get infected and lead to viremia. The infected cells release interferons which aid the recruitment of B cells that release the antibodies, IgG and IgM and the cytotoxic T cells which target the infected cells. The complement system and NK cells are also recruited to neutralize the virus. The B cells also produce memory B cells in case the patient is infected again however, these memory cells will only be able to help if the patient is infected with the same serotype again $[64,65]$. The figure was created using BioRender and exported under the terms of premium subscription.

While some of the infected Langerhans travel to the lymph nodes (small glands present throughout the body that are known to fight infections) to trigger the immune response, the remaining secrete proteins called interferons which disrupt the replication process of viruses through the activation of innate and adaptive immune system defenses (Figure 2) [24,48]. They help in the recognition of the infected cells and protection of the uninfected cells. The individuals experience dengue fever (DF) while their body's immune system fights the virus. Antibodies from B cells, immunoglobulin M (IgM) and IgG are secreted into the bloodstream and the lymph fluid in order to neutralize the virus while on the other hand, cytotoxic $T$ cells and killer $T$ cells are used in order to specifically recognize and destroy the virus through adaptive immune mechanisms. The innate immune response further activates the complement system in order to destroy the virus with the help of antibodies and leukocytes, clearly indicating the contribution of both the immune systems, in order to neutralize the dengue infection [49].

The individual remains protected from the other three serotypes for about 2 to 3 months after recovery from the first dengue infection. However, this provides short term protection only and the usual observation was that a second dengue infection was much worse in individuals infected beforehand than those who were not infected earlier $[47,50]$. Even though the memory B cells and memory $\mathrm{T}$ cells are normally known to provide protection through adaptive immune response when the virus strikes again, the mechanism fails in case of a second dengue attack. These observations were explained by Halstead through the "antibody-dependent enhancement of infection" phenomenon which supports the idea that the antibodies present from the first dengue infection or the newly produced memory B cells facilitate the efficient viral attack of host cells instead of providing protection against the other three serotypes [50,51-55]. This happens since the antibodies from the first dengue infection form a complex with the newly attacking serotype which further binds to the $\mathrm{Fcy}$ receptors (FcyR) present on different immune cells [56-60]. This results in severe dengue fever, also known as dengue hemorrhagic fever (DHF), since more cells are infected with the help of the preexisting antibodies. This phenomenon is also active among children who received antibodies for dengue from their mothers while in the womb, putting them at a greater risk of developing severe dengue $[61,62]$. Furthermore, different immune cells are involved in releasing elevated amounts of cytokines, a phenomenon known as the cytokine storm, following DENV infection. The release of elevated levels of cytokines involve interleukin-10 (IL-10), interferon alpha (IFNa), tumor necrosis factor alpha (TNF- $\alpha$ ) etc. which lead to the inflammation. IL-6, Monocyte chemoattractant protein 1 (MCP- 
Table 1. The symptoms associated with dengue fever

\begin{tabular}{|c|c|c|c|}
\hline Phase & Time Interval & Signs and Symptoms & References \\
\hline $\begin{array}{l}\text { Febrile } \\
\text { Phase }\end{array}$ & Day 1-3 & $\begin{array}{l}\text { - High grade fever, usually over } 40^{\circ} \mathrm{C} / 104 \mathrm{~F} \\
\text { - Body ache, petechiae, myalgia, arthralgia, headache, anorexia, vomiting } \\
\text { - Bleeding of mucosal membrane (nose and gums), gastrointestinal bleeding (rare) and } \\
\text { massive vaginal bleeding (in women of childbirth age) } \\
\text { - Lasts } 2 \text { to } 7 \text { days }\end{array}$ & $\begin{array}{l}69,71] \\
{[74-83]}\end{array}$ \\
\hline Critical Phase & Day 4-5 & $\begin{array}{l}\text { - Occurs around defervescence } \\
\text { - There is a drop in temperature: } 37.5-38^{\circ} \mathrm{C} \text { or less } \\
\text { - Blood plasma leakage, leukopenia, plasma leakage } \\
\text { - Shock, severe organ impairment, metabolic acidosis and disseminated intravascular } \\
\text { coagulation (as a result of shock) } \\
\text { - Lasts } 1 \text { to } 2 \text { days }\end{array}$ & $\begin{array}{l}{[79]} \\
{[81]} \\
{[84,85]}\end{array}$ \\
\hline Recovery Phase & Day 6 onwards & $\begin{array}{l}\text { - General feeling of well-being, improvements in appetite, gastrointestinal symptoms abate } \\
\text { - Reabsorption of leaked fluids } \\
\text { - Hemodynamic status stabilizes and diuresis ensues } \\
\text { - Rash with a maculopapular or vasculitic appearance, chronic fatigue } \\
\text { - May lead to hypervolemia (in case of excessive intravenous fluid therapy) } \\
\text { - Lasts } 2 \text { to } 3 \text { days }\end{array}$ & {$[74,79,84,86]$} \\
\hline
\end{tabular}

1), C-X-C motif chemokine 10 (CXCL10) are also accused to worsen the disease condition and significantly contribute to dengue pathogenesis [63].

As dengue virus attacks our body, our body's innate and adaptive immune systems defend us through the recruitment of several cells which eventually help to neutralize the virus. A clearer understanding of the pathogenesis of DHF facilitates early detection of severe diseases as well as accurate management.

\section{SYMPTOMS AND CLINICAL PRESENTATION}

\section{Signs and Symptoms}

The signs and symptoms of dengue virus infection depends on the severity of the case, and it can even be asymptomatic. Although, infections are asymptomatic in almost $75 \%$ of infected patients, however, if they do make an appearance, they begin 3 to 14 days (incubation period) after the initial infection [66]. It can be severe in about $5 \%$ of the cases and in less than $1 \%$, it may be life-threatening and eventually lead to death, despite intensive care. Dengue fever (DF) results in a high-grade fever further leading to a number of other symptoms which include headache, retro-orbital pain, muscle pain, vomiting and rash. The symptoms may become worse and life-threatening if the disease is moderate or severe $[67,68]$. The symptomatic cases are classified into undifferentiated febrile illness (UF), dengue fever (DF), dengue hemorrhagic fever (DHF), dengue shock syndrome (DSS) and unusual dengue (UD) or expanded dengue syndrome (EDS) [69]. Due to damaged blood vessels, blood plasma leakage and a decreased platelet count, the risk of acquiring dengue hemorrhagic fever (DHF) increases. The symptoms may also progress to massive bleeding, shock, and death; this is called dengue shock syndrome (DSS). Dengue infections and DHF severity can be classified into several groups according to the visibility of certain signs and symptoms, and also with the help of laboratory evaluations.

They are as follows: [70]

- Dengue Fever (DF): Patients may experience fever along with two other symptoms which may include rash, myalgia, headache, hemorrhagic manifestations but, no signs of plasma leakage. These patients will also experience leukopenia (white blood cell count $\leq 5000$ cells/mm3), thrombocytopenia (platelet count $<150$ 000 cells $/ \mathrm{mm} 3$ ) and a rising hematocrit (HCT) level of about $5 \%-10 \%$.

DHF severity can be further classified into 4 grades:

- DHF - I: The patients will experience fever and hemorrhagic manifestations followed by plasma leakage. Among others, they will have thrombocytopenia with WBC $<100000$ cells $/ \mathrm{mm} 3$ and a HCT rise $\geq 20 \%$

- DHF - II: Symptoms along with thrombocytopenia level and $\mathrm{HCT}$ rise follow that in DHF I, with additional bleeding (spontaneous)

- DHF - III: Symptoms along with thrombocytopenia level and HCT rise is similar to Grade I or II, and also leads to circulatory failure

- DHF - IV: Profound shock with undetectable BP and pulse along with Grade III characteristics

The course of dengue infection takes off after the incubation period and is divided into 3 main phases: Febrile phase, critical phase (which may include hemorrhagic manifestations and/or dengue shock syndrome), recovery or convalescence phase (Table 1) [71-73].

\section{Prognostic Factors}

The prognostic factors of dengue enable the better monitoring of the patients to check for the visibility of any present abnormalities. The development of shocks as a result of the rise in the hematocrit values (due to plasma leakage), can be prevented with the help of early volume replacement. Similarly, serial determinations of platelet and hematocrit values can also help in early recognition as well as the prevention of shocks [87]. Hematocrit greater than $40 \%$ is a possible prognostic factor for dengue infection severity, particularly DSS. Vasculopathy (a disease affecting blood vessels) in dengue infection causes the vascular permeability to increase, leading to hemoconcentration and shock. One of the WHO criteria to diagnose DHF is a hematocrit value of greater than or equal to the initial value. According to several studies, bleeding episodes were found to be associated with thrombocytopenia (found in severe dengue infection), which could also be a prognostic factor for the disease. A systolic 
blood pressure of less than $90 \mathrm{mmHg}$ and a pulse pressure less than or equal to $20 \mathrm{mmHg}$, are considered to be the prognostic factors for DSS [88]. Furthermore, elevated levels of aminotransferase (aspartate aminotransferase and alanine aminotransferase) from the liver, is also known to be associated with thrombocytopenia and leukopenia.

Similarly, it was observed that a decrease in the platelet count led the patients to a state of shock. WHO provided an overview of the platelet count to categorize dengue infection into DHF grades, from I to IV [89]. A study showed that, compared to healthy patients and those with non-dengue febrile illness, dengue infected patients in their critical stage showed elevated levels of Galectin-9 (Gal-9). While the Gal-9 levels were observed to be high in DF and DHF, they were found to be significantly lower during the recovery phase. Since Gal-9 was observed to track dengue inflammatory responses, it can be used as a possible novel biomarker of acute DENV as well as for disease severity [90]. In another study, when plasma biomarkers in severe dengue patients were examined, plasma proteins such as PFKFB4, TPM1, PDCL3 and PTPN20A were highly expressed in patients with severe dengue in comparison with other forms of dengue diseases [91]. The total cholesterol and LDL-cholesterol levels can also be used as markers for dengue severity. This was observed in a study where lower levels of circulating cholesterols were found to be associated with the risk of developing severe dengue [92]. Furthermore, elevated liver enzymes (SGOT and SGPT) are also known as prognostic factors for DSS however, they are not routinely investigated in many hospitals and are therefore known to be less frequently used as prognostic factors.

Similarly, monitoring prognostic factors i.e., normalized WBC count, platelet count, hematocrit level etc., can help to keep a track on the patient's improvement and recovery. And assessing the improvement and the deteriorating condition of a patient with the help of prognostic factors further help in the diagnosis and management of patients.

\section{Management of Patients}

The management of dengue patients depends on the phase of illness, i.e. the febrile phase, the critical/leakage phase and the recovery or convalescence phase. For the febrile phase, patients should only be given supportive and symptomatic treatment which may include the use of paracetamol or tepid sponge for fever reduction, promoting oral feeding with the help of fruit juice, milk or oral rehydration therapy (ORS) and avoiding IV fluids if the patient is not vomiting or dehydrated. Patients are advised to follow up CBC every day and to return to the hospital if no improvement is seen $[69,93]$.

For the critical phase, isotonic salt solution is used except in the very young infants ( $<6$ months of age), in whom $0.45 \%$ sodium chloride may be used. The total amount of fluid needed during this period of 24-48 hours is estimated to be maintenance $+5 \%$ deficit (according to guidelines stated by WHO), including oral and IV fluids [94]. In DSS patients the duration of IV fluid may be 24-36 hours and in non-shock DHF patients, $48-60$ hours. The rate of IV fluid should be adjusted according to the clinical vital signs such as blood pressure (BP), pulse, respiratory rate, temperature or the hematocrit and urine output, and also according to the grade of severity of dengue. Hyper-oncotic colloid solutions (osmolarity of $>300$ $\mathrm{mOsm} / \mathrm{l}$ ) such as dextran 40 or starch solutions can be used in patients with massive plasma leakage [95]. In case of a lack of a positive clinical response, patients showing unstable vital signs or other negative signs are further investigated and treated for acidosis (corrected with $\mathrm{NaHCO}$, if $\mathrm{pH}$ is $<7.35$ and serum bicarbonate is $<15 \mathrm{mEq} / \mathrm{L}$ ), bleeding, iCa and other electrolytes ( $\mathrm{Na}$ and $\mathrm{K}$ ), and blood sugar. Furthermore, in cases of significant bleeding, blood transfusion is recommended as soon as possible [96]. Platelets are indicated in cases with significant bleeding. However, it may cause fluid overload and possible acute pulmonary edema in patients who already show signs of fluid overload. Plasma and steroids do not play a role in the management of acute DHF and DSS, respectively. Patients with obesity or diabetes mellitus are advised to get blood glucose levels examined and those experiencing prolonged/profound shocks should take additional tests in order to monitor them accordingly [97].

During the convalescence/recovery phase, IV fluids should be stopped upon signs of recovery (increase in appetite, convalescence rash, greater than 30 hours before shock, etc). Patients who fail to regain their appetite as a result of potassium loss through urine or diuresis, are recommended a potassium rich diet. This is the period of reabsorption and therefore, patients with massive ascites and pleural effusion may require diuretics.

As mentioned earlier, the rate of IV fluid also depends on the severity of dengue i.e., according to the different grades of DHF. DHF I and II which involves non-shock patients, the fluid allowance (oral + IV) is about maintenance (for one day) $+5 \%$ deficit (oral and IV fluid together), to be administered over 48 hours [98]. The rate is different between children and adults and often follows ideal weight measures. The rate of IV replacement should be adjusted according to the rate of plasma loss, following the clinical condition, vital signs, urine output and hematocrit levels.

DHF III, which includes shock or DSS, is caused due to plasma leakage that leads to an increased systemic vascular resistance and narrowed pulse pressure [99]. Patients must be checked for bleeding or gastrointestinal bleeding along with the plasma leakage in cases of hypotension. Fluid resuscitation in DSS is different than other types of shocks and patients usually respond to the $10 \mathrm{ml} / \mathrm{kg}$ in children or $300-500 \mathrm{ml}$ in adults over one hour or by bolus procedure or, follow a particular rate of infusion chart/graph and also, before reducing the IV replacement rate, the patient must be checked for improvements.

For DHF IV (prolonged/profound shock), in order to restore the blood pressure, the initial fluid resuscitation is vigorous and also, other laboratory tests must be done and treated for. $10 \mathrm{ml} / \mathrm{kg}$ of bolus fluid should be given within 10 to 15 minutes. After BP restoration, IV fluids can be given however, if shock is not reversible after the first $10 \mathrm{ml} / \mathrm{kg}$, a repeat bolus of $10 \mathrm{ml} / \mathrm{kg}$ should be given and the laboratory tests must be continued to check for correction and progress [100]. Patients should be closely monitored, given blood transfusions in case of need and managed accordingly in case of organ impairments.

Patients with severe hemorrhage may take blood transfusions in order for the HCT levels to drop to normal. Apart from this, several other measures can be taken. Patients who are at high risks such as, obese patients, infants, pregnant women, patients with diabetes mellitus or heart diseases along with those experiencing a fluid overload or encephalopathy (damage or disease affecting the brain), must be cared for and managed accordingly in order to prevent any further health complications [101]. 
A better understanding of the signs and symptoms of dengue along with the frequent monitoring of the prognostic factors and the application of adequate measures for the better management of patients, can contribute greatly for a quick recovery.

\section{EPIDEMIOLOGY OF DENGUE VIRUS INFECTION}

Dengue is an important arthropod borne viral disease that is known to affect an estimated 2.5 billion people around the globe; approximately 975 million are habitants of the urban areas in tropical and subtropical countries in Southeast Asia, the Pacific and America [4,102-105]. The transmission range also covers the African, the Eastern Mediterranean and the rural communities. The number of cases reported each year includes more than 500 million infected and about 500,000 individuals hospitalized for dengue hemorrhagic fever $[6,106,107]$.

The first epidemic of dengue dates back to 1635 in the French West Indies and similarly, a disease outbreak identical to dengue was reported in China during 992 AD [108,109]. The 1779-1780 dengue outbreaks in Asia, Africa, and North America along with simultaneous outbreaks in three other continents indicated the world-wide distribution of the virus and their mosquito vectors. According to the World Health Organization (WHO), the average annual number of reported cases for DF or DHF includes 925,896 people during the 2000-2004 period which is double that of 1990-1999, indicating an overwhelming increase in confirmed cases. Again, from 2000 to 2008, the average annual number of cases reported was $1,656,870$ which is almost three and a half times that noted previously. While there were little to no cases in the African or Eastern Mediterranean regions in the 2005-2006 period, countries such as Pakistan, Saudi Arabia, Yemen, Sudan and Madagascar had suspected outbreaks [110]. There was an expansion of the dengue transmission regions worldwide, that included the four existing serotypes of dengue and the leading factors could have been the travelling of individuals from endemic regions acting as carriers, uncontrolled vectors, unprecedented population growth and uncontrolled urbanization [107,111114].

\section{Dengue in Asia}

After World War II, the global pandemic of dengue emerged in Southeast Asia and almost $75 \%$ of the world's dengue burden involved countries such as the Philippines, Indonesia and Thailand [115]. Also, following the years of World War II, the unprecedented urbanization led to inadequate housing, deterioration of water, sewer and waste management systems in Southeast Asia. This ecological setting facilitated the increase in transmission and frequency of epidemics. Apart from the economic expansion, the migration of people to different cities and countries also led to the cocirculation of the different serotypes resulting in the hyperendemicity [116]. Furthermore, apart from an adaptable climate for the vectors, population growth and global travel has also led to an increase in the spread of the virus. Even though DHF had appeared first as an epidemic in the 1950s, it had become one the leading causes of hospitalizations and death by $1975[16,117]$. DHF had expanded into Asia during the 1980s and China and Taiwan also reported cases of epidemic DF after an absence for 35 years.
After a successful control program, Singapore was able to prevent transmission for over 20 years [118]. Even though only sporadic cases of dengue were reported before 2000, it raised a serious public health concern during 2000 with 5,551 reported cases and 93 deaths $[103,119,120]$. Countries like Timor-Leste, Bhutan and Nepal had also reported their first dengue outbreaks in the year 2004. Soon after dengue had become endemic in several regions throughout the years, by the end of 2016, countries such as China, Malaysia and Singapore had reported about 2,91,964 cases [121]. Also, the cases of dengue had spiked ever since its first outbreak with DEN- 3 during the year 2000, in Bangladesh [122,123].

\section{Recent Dengue outbreaks in Asia (2019-2020)}

Recently, dengue outbreaks were reported to be a terrifying epidemic in many countries of Asia. By the end of 2019 , a total of 101,354 cases and 179 deaths were reported in Bangladesh. Again, this country recorded about 263 cases till 16th of March in 2020 [124,125]. While Malaysia reported a cumulative number of 127,407 cases and 176 deaths as of December 21, 2019, the Philippines reported 420,453 cases including 1,565 deaths till December 14 of the same year and Singapore reported about 15,622 cases on week 51 of 2019 [126]. Dengue transmission was also recorded in Afghanistan for the first time, in 2019. China reported 268 cases in January 2020, Malaysia reported 32,951 cases including 48 deaths from December 29, 2019 till March 21, 2020, Philippines reported 37,058 cases including 112 deaths as of February 2020 and Viet Nam reported 20,673 cases including 4 deaths until March 20, 2020 [127].

\section{Dengue in America}

Dengue has been a major public health problem in America. A campaign by the Pan American Health Organization (PAHO) played a role in the eradication during the 1960 s from the central and south American countries [128]. The discontinuation of the campaign in the 1970s further led to the reinfestation of the species. In the 1970s, DEN-2 and DEN-3 were present in America however, the major epidemic in 1977 was due to the DEN-1 virus which had an epidemic period of 16 years. In 1981, DEN-4 was introduced along with another strain of DEN-2 from Southeast Asia which led to a major DHF epidemic and this new strain caused outbreaks in Venezuela, Puerto Rico, Columbia, Brazil, French Guiana, the French Antilles and Suriname [129]. A total of 14 countries in America had endemic DHF after its emergence in 1995. The failed eradication program led to an increase in infected cases from 2000 to 2010 and therefore, over 1.7 million cases were reported including 50,235 severe cases and 1,185 deaths. According to a recent report by WHO, the number of cases increased by 15 fold over the past two decades with an increase from 50,5430 cases in 2000 to 2,400,138 cases in 2010 [130]. In November 2018, PAHO had alerted the countries to increase their preparedness and response efforts in order to prepare for a much intense dengue outbreak. Following that, according to a report from PAHO, America recorded the largest outbreak of dengue with about 3 million cases in the region until 2019 and the number of cases reported was 320,000 as of February 9, 2020 [131]. Reports from the 2019 dengue cases also suggested additional findings such as an increase in severe dengue cases, shifts in epidemic season and a higher risk of death for the younger age groups (5-9 years). The early and appropriate diagnosis and clinical management of patients along with effective ways of breeding site destruction, and tackling the 
social and environmental determinants that are linked to dengue can help slow down and eventually stop the disease transmission, preventing further deaths.

\section{Dengue in Australia}

The first outbreaks in Australia date back to 1879 in Queensland at Townsville and 1885 in Rockhampton [132]. In 1898 , the first cases were reported in New South Wales and during 1925-26 it extended to the south. In the Northern Territory, it was prevalent during 1955 [133-135]. By the end of the $19^{\text {th }}$ century, dengue was widely distributed and it further spread through various mediums which included the presence of major breeding sites provided by rainwater tanks and waterholding domestic containers. The species had soon disappeared from the northern and western parts. There was a reduction in the population during the 1960s in Queensland however, after it's disappearance for 25 years, it had reappeared during the 1980s [136-138]. Several factors had influenced its decline; the leading factor being the conversion of urban water supplies from household rainwater tanks to a reticulated supply, change from steel to diesel locomotives, the use of domestic insecticides along with public education and increased awareness had all contributed greatly. In four years, from 2005 to 2008, nine outbreaks of dengue were reported in Queensland, Australia [139]. On December 1, 2008, a dengue outbreak was declared in the tropical north region of Queensland, Cairns and several confirmed cases were reported soon after in 2009 affecting towns and cities like Townsville, Port Douglas, Yarrabah, Injinoo, Innis fail and Rockhampton . Also, from the period 2005-2006 to 2009-2010, the number of dengue cases had increased from 156 to 581 . Australia reported a total of 1,419 cases till December 18,2019 , since the start of the year and about 78 cases as of February 26, 2020 [127,140]. In Australia, dengue occurs seasonally in northern Queensland, with a peak transmission from January to April. Even though dengue is not endemic in Australia, the presence of the vectors, Aedes Aegypti and Aedes Albopictus mosquitoes raises the risk of a possible outbreak.

\section{Dengue in Europe}

Dengue was endemic in regions of southern Europe until the 1930s due to the presence of Aedes Aegypti. In 1927 and 1928, several outbreaks infected millions and led to a death toll of around 2100 in Greece and Turkey [141]. Disappearance of the disease was noted however, several locally transmitted cases in Croatia, France and Portugal were also reported; Ae. Albopictus and Ae. Aegypti being the responsible vectors. From the period 2012-2013, a large outbreak in Madeira and Portugal was reported which not only included more than 2100 cases but also involved the spread of the disease to 14 other European countries [142]. The leading causes included the introduction of the efficient mosquito vector species and the arrival of infected people. According to a report from WHO, Ae. Albopictus had been spreading and was known to have established from Spain to Greece and also to the Eastern countries and the Black sea coast. In the year 2019, over 15,000 autochthonous cases of dengue were confirmed till June 11, including at least 9 deaths by the end of the year [143]. Several surveillance and control programs for dengue vectors are available in the European countries but only a few selected programs include the disease apart from the vector as well. The dengue transmission models that represent Europe, suggest that Europe is at a lower risk but they rarely include the transmission of the other vector, Aedes Albopictus [110,144].
The unavailability of any specific treatment makes integrated vector management the only sustainable control option.

Several factors contribute to the facilitation of the dengue vectors for their survival and transmission along with the presence of different serotypes. The adaptation of better surveillance systems and control programs alongside individual preventive measures by the countries can help reduce the cases of dengue, and the following deaths.

\section{DIAGNOSTIC METHODS}

The accurate and efficient diagnosis of dengue is significant in order to differentiate dengue from other diseases such as leptospirosis, rubella, and other infections caused by flavivirus. Successful diagnosis also helps to provide clinical care and surveillance support to the patients as well as to carry out pathogenesis studies and vaccine research along with the case confirmation of DHF/DSS. During the first 5 days of illness, dengue virus and antigen detection are the most accurate diagnostic tools, as IgG and IgM antibodies are not produced until 5-7 days after the onset of symptoms in primary infections $[145,146]$. Rapid Diagnostic Tests (RTDs) are a simple and quick way of screening for dengue virus especially in countries that do not have the facilities to perform tests such as ELISA or PRNT tests. However, RTD has its own share of disadvantages as they cannot detect past DENV infections in the patient and might lack sensitivity and specificity in order to ensure management and clinical care of the infected patients [147].

Another method of directly testing for the DENV virus is the Dengue non - structural protein NS1 antigen test which is a serotype - specific identification test and is used for early detection, that is, less than five days since the onset of the fever. NS1 test has been the most popular as it is rapid and less costly than other methods such as viral isolation or viral reverse transcriptase-polymerase chain reaction [148]. When mammalian cells are infected, during the acute phase of the infection, they secrete the NS1 antigen which is a glycoprotein synthesized by all flaviviruses [149]. Although NS1 tests are the most effective dengue detection tests so far, NS1 tests alone cannot determine the serotype of the DENV infection and is mainly an indicative test [150].

There are few other different effective DENV diagnosis methods available but the plaque reduction test (PRNT) has been the most widely used method of identifying the immune response to dengue virus. Although the basis of the test has remained the same, over the years, the methods and materials have been modified in different laboratories [151]. As the PRNT method of detecting DENV is a time-consuming process, several different methods have been developed for fast and efficient detection of DENV. The advantages and disadvantages of those methods have been analyzed by taking different factors into account like the type of biomarkers, the sensitivity, accuracy, rate of detection as well as the possibility of commercialization, linear range, availability, limit of detection, simplicity, mechanism of detection, and if it can be used for clinical applications. The main methods that have been found are the optical, electrochemical, microfluidic, enzyme linked immunosorbent assay (ELISA), and smartphone-based biosensors methods that detect different serotypes and biomarkers (Table 2) [152].

The Dengue NS1 test is the most effective dengue test till date, even though it has its own setbacks, as it is cost effective, 
Table 2. Different DENV identification techniques. NA: Not allowed

\begin{tabular}{|c|c|c|c|c|}
\hline Technique Name & Basis of Test & Advantages & Disadvantages & References \\
\hline $\begin{array}{l}\text { Plaque-reduction neutralization } \\
\text { test (PRNT) }\end{array}$ & $\begin{array}{l}\text { Plaques forming units } \\
\text { (PFUs) are counted }\end{array}$ & $\begin{array}{l}\text { The most serotype specific test and is the } \\
\text { standard for all other tests }\end{array}$ & $\begin{array}{l}\text { Labour intensive and difficult to } \\
\text { use in a large-scale basis }\end{array}$ & {$[153]$} \\
\hline $\begin{array}{l}\text { SYBR green reverse transcription } \\
\text { polymerase chain reaction (SYBR } \\
\text { green RT-PCR) }\end{array}$ & DENV genome & $\begin{array}{l}\text { Detection rate and sensitivity are higher } \\
\text { than conventional RT-PCR }\end{array}$ & NA & {$[154]$} \\
\hline $\begin{array}{l}\text { Electron immunomicroscopy } \\
\text { (EIM) }\end{array}$ & Viral Polypeptides & Sensitive & $\begin{array}{l}\text { Complex maintenance, sample } \\
\text { preparation and high cost. }\end{array}$ & {$[155]$} \\
\hline Optical biosensors & Photons & $\begin{array}{l}\text { More accurate and precise compared to } \\
\text { conventional methods }\end{array}$ & NA & {$[156,157]$} \\
\hline Photonic crystal biosensors & Refractive index & Rapid and sensitive & $\begin{array}{l}\text { Highly sensitive to surface } \\
\text { contamination }\end{array}$ & {$[158,159]$} \\
\hline $\begin{array}{l}\text { Vertical-cavity surface emitting } \\
\text { laser (VCSEL) method }\end{array}$ & $\begin{array}{l}\text { Detects anti-dengue IgG } \\
\text { antibodies }\end{array}$ & Higher sensitivity than ELISA method & False-positive errors & {$[160]$} \\
\hline Colorimetric biosensors & PNA/DNA hybridization & $\begin{array}{l}\text { simple, fast response, acceptable } \\
\text { sensitivity, selectivity and is efficient }\end{array}$ & $\begin{array}{l}\text { Unmodified gold nanoparticles } \\
\text { are used (Au NPs) }\end{array}$ & {$[161,162]$} \\
\hline $\begin{array}{l}\text { Surface-enhanced Raman } \\
\text { scattering (SERS) biosensors }\end{array}$ & $\begin{array}{l}\text { Dengue virus (serotype 4) } \\
\text { oligonucleotide } \\
\text { sequences }\end{array}$ & $\begin{array}{l}\text { Highly sensitive optical detection } \\
\text { technique and a multiplexed readout }\end{array}$ & $\begin{array}{l}\text { Ag-Au bimetallic nano wave } \\
\text { chips are used }\end{array}$ & {$[163,164]$} \\
\hline $\begin{array}{l}\text { Surface Plasmon resonance } \\
\text { (SPR) based biosensors }\end{array}$ & Antibody detection & $\begin{array}{l}\text { Optical label free, cheaper than virus } \\
\text { isolation or RT PCR }\end{array}$ & $\begin{array}{l}\text { Low sensitivity and specificity. } \\
\text { Temperature, size of biosensor } \\
\text { and optics are difficult to } \\
\text { regulate }\end{array}$ & {$[165,166,167]$} \\
\hline Fluorometric biosensors & Dengue virus & Accurate and sensitive & $\begin{array}{l}\text { Use of Au NPs. High background } \\
\text { signals. }\end{array}$ & {$[168,169]$} \\
\hline $\begin{array}{l}\text { Enzyme linked immunesorbent } \\
\text { assay (ELISA) }\end{array}$ & $\begin{array}{l}\text { Antigen/antibody } \\
\text { detection }\end{array}$ & Sensitive and specific & $\begin{array}{l}\text { Time-consuming, specific and } \\
\text { expensive laboratory equipment } \\
\text { and expert technicians are } \\
\text { required. }\end{array}$ & {$[170,171,172]$} \\
\hline Sandwich ELISA & Biomolecule & $\begin{array}{l}\text { More reliable, sensitive and specific than } \\
\text { ELISA method }\end{array}$ & NA & {$[173,174]$} \\
\hline $\begin{array}{l}\text { Reverse transcription loop- } \\
\text { mediated isothermal } \\
\text { amplification (RT-LAMP) }\end{array}$ & DENV genome & $\begin{array}{l}\text { Efficient, cheap, provides accurate and } \\
\text { reliable results }\end{array}$ & NA & {$[175]$} \\
\hline Voltammetric biosensors & $\begin{array}{l}\text { Current measured based } \\
\text { on oxidation/reduction }\end{array}$ & $\begin{array}{l}\text { Cost effective, readily available, and rapid } \\
\text { detection. Can also detect low amounts of } \\
\text { viral antigens accurately. }\end{array}$ & $\begin{array}{l}\text { Developing portable and simple } \\
\text { operation electrochemical } \\
\text { devices are a challenge. }\end{array}$ & {$[176,177,178]$} \\
\hline Amperometric biosensors & $\begin{array}{l}\text { Current measured based } \\
\text { on oxidation/reduction }\end{array}$ & $\begin{array}{l}\text { High selectivity, sensitivity in ultra-dilute } \\
\text { samples, and commercial availability. }\end{array}$ & NA & {$[179,180]$} \\
\hline Impedimetric biosensors & Current/Voltage ratio & $\begin{array}{l}\text { High detection capability and ability to } \\
\text { report charge transfer resistance during } \\
\text { hybridization process. }\end{array}$ & NA & {$[181,182,183]$} \\
\hline $\begin{array}{l}\text { Electrochemical impedance } \\
\text { spectroscopy (EIS) }\end{array}$ & $\begin{array}{l}\text { Changes in charge } \\
\text { transfer resistance }\end{array}$ & $\begin{array}{l}\text { High sensitivity and ability to report } \\
\text { charge transfer resistance }\end{array}$ & NA & {$[184]$} \\
\hline Conductometric biosensors & DENV nucleic acid & Cheap and high sensitivity & NA & {$[185]$} \\
\hline $\begin{array}{l}\text { Metal oxide based electronic } \\
\text { biosensors }\end{array}$ & $\begin{array}{l}\text { Nucleic acids, alkali metal } \\
\text { ions and proteins }\end{array}$ & $\begin{array}{l}\text { Ultra- low detection capabilities, low } \\
\text { assay time, and availability }\end{array}$ & $\begin{array}{l}\text { Debye length, restricting the } \\
\text { detection of large biomolecules } \\
\text { such as DNAs and RNAs }\end{array}$ & {$[186,187]$} \\
\hline Microfluidics system & DENV antibodies & $\begin{array}{l}\text { Low consumption of reagents, minimal } \\
\text { handling of materials, less time } \\
\text { consuming, multiplex analysis, } \\
\text { portability, and versatility in design }\end{array}$ & NA & {$[188]$} \\
\hline Smart phone-based methods & Dengue viruses & $\begin{array}{l}\text { Popular, portable, data acquisition and } \\
\text { transferring abilities, high-quality camera } \\
\text { lenses and cost-effectiveness }\end{array}$ & NA & {$[189]$} \\
\hline $\begin{array}{l}\text { Silicon nanowire (SiNW) } \\
\text { biosensor }\end{array}$ & PNA (peptide nucleic acid) & $\begin{array}{l}\text { Rapid and Sensitive, sample labelling is } \\
\text { not required }\end{array}$ & $\begin{array}{l}\text { May fluctuate with nucleic acid } \\
\text { mutation, may be less effective } \\
\text { in viremia phase. }\end{array}$ & {$[190]$} \\
\hline $\begin{array}{l}\text { TaqMan real-time one-step RT- } \\
\text { PCR }\end{array}$ & Polymerization reaction & $\begin{array}{l}\text { More specific and significantly reduces } \\
\text { false positive. }\end{array}$ & Laborious. & {$[191]$} \\
\hline
\end{tabular}

rapid and simple. Although there are several techniques available that vary in mechanism, sensitivity, specificity, the application of all these techniques depend on the cost, expertise and laboratory facility etc. of a country. Therefore, the demand to develop a more common diagnosis technique that is altogether cost effective, rapid, specific and sensitive still remains and may require more research. 


\section{PREVENTION AND TREATMENT STRATEGY}

As there is no proper drug or direct vaccine available to this day, prevention of dengue is extremely important in order to handle the spread of this disease. The DENV is spread by a human-to-mosquito-to-human cycle by the Aedes mosquito [192] thus most strategies to prevent spread of the virus includes preventing the growth of mosquitoes and laying of eggs. The measures to be taken include proper disposal of solid waste, cleaning water storage containers every week and applying insecticides in those containers. Water storage tanks must be covered at all times and appropriate insecticides must be added to the water. Additionally, means of personal protection must also be used such as long-sleeved clothes, window screens, coils, vaporizers etc. During outbreaks, spraying insecticides inside the households and thorough monitoring must be carried out to prevent infection $[128,193,194]$.

The life cycle of dengue virus involves the entry of the virus into our body, membrane fusion, RNA genome replication, assembly, and ultimate release from the infected cell. Thus, the treatment of dengue is not specific and remains to be supportive [195]. Supportive treatment includes oral fluid administration and antipyretic treatment with paracetamol along with daily full blood counts. If there is excessive vomiting or diarrhea observed, admission to hospital is necessary to avoid dehydration. The patient must be administered oral fluid as much as possible [196]. The symptoms of dengue are flu-like and so there is no specific treatment but an early diagnosis and clinical management can reduce the severity of the effects of dengue on the body $[128,197]$.

Currently, there is no licensed antiviral agent available against dengue as the drug needs to address all four serotypes of the dengue virus. Researchers have been trying to develop drugs by targeting several different steps in the disease pathway in order to interfere with the replication of dengue virus. For example, nucleoside analogue blocks a dengue infection by preventing synthesis of the viral RNA genome so that the dengue virus cannot replicate. Viral replication can be difficult to prevent because there is a short timeline for treatment which is why it is important to target other steps in the disease pathway to prevent dengue at later stages [198]. Therefore, steps other than viral replication such as protein synthesis and viral assembly may be potential targets to produce a vaccine or drug for dengue and thus require further research.

\section{VACCINE FOR DENGUE VIRUS}

A vaccine can boost the immune system in our body against a particular pathogen which is paramount in order to fight against viral diseases such as one caused by DENV. But unfortunately, no effective direct vaccine has been discovered yet that can successfully combat the dengue infection. There is a major array of concerns that need to be addressed in order to produce a direct vaccine which is why producing one has been a major challenge. The mutation rate of viruses like DENV is the major hurdle to develop an effective vaccine. Additionally, the vaccines produced must work against all four of the DENV serotypes and must provide lifelong protection. This may be done by incorporating an antigen that is common for all four serotypes. As vaccines with live, attenuated or nonliving viruses usually produce less antibody than an infection with wild-type virus, it is most likely that two doses of the virus will be required. Several other factors need to be taken into account such as the level of symptoms seen after the vaccination, if the vaccine can be used by people of all ages and the cost of the vaccine etc. [192,199].

Providing lifelong protection against all four serotypes by neutralizing antibodies is difficult due to antibody-dependent enhancement (ADE) or immune enhancement. ADE observed during dengue infection due to heterologous non-neutralizing antibodies may cause dengue hemorrhagic fever (DHF) or dengue shock syndrome (DSS) during secondary infection by a different serotype. Additionally, over time, antibody responses below protective levels may increase the possibility of immune enhancement by a natural infection due to wild type DENV. Another major challenge of producing a dengue vaccine is the lack of an appropriate human like animal model for the trials of the vaccines which will allow us to observe the pathogenesis, immune response and clinical course of dengue infection in humans. Inoculation of mouse-adapted DENV strain into suckling mice through intracerebral route has caused paralysis or death of that animal [200].

So far only one such vaccine for dengue has been approved, Dengvaxia $^{\circledR}$ (CYD-TDV). Dengvaxia ${ }^{\circledR}$ (CYD-TDV) has been developed by Sanofi Pasteur and it is for people who have already been infected by DENV once. This works on people ages 9 to 45 and must be given three doses in intervals $[126,193,201]$. However, a large number of vaccines are now in different phases of clinical trials in different companies (Table 3 ).

Pre - Clinical trials include conducting the research in lab assays or on animals. This includes identification of relevant antigens, creating a vaccine, testing it on lab animals and test tubes, and lastly, using proper manufacturing standards to manufacture the vaccine. Finally, clinical trials are carried out to assess the safety and efficacy of agents under investigation in the four phases including different size of volunteers (Table 4) $[214,215]$.

Although there are several issues and concerns related to producing vaccines that are close to a hundred percent successful, given the demand all over the world, it is vital to produce a vaccine even if a lot of time is required so that a dengue outbreak can be fought against.

\section{CURRENT STATUS AND FUTURE PROSPECTS OF DENGUE RESEARCH}

A lot of effort has been put into preventing and controlling a potential dengue pandemic by scientists and researchers all over the world. Research has continuously been going on for years to secure specific countermeasures or vaccines to prevent the dengue outbreak. Recently, a new serotype of dengue virus known as DENV 5 was reported in October 2013 which is similar to DENV 2 and follows the sylvatic cycle rather than the human cycle that the other four serotypes follow [216]. It has been found that DENV-5 constitutes a unique, distinct phylogenetic group, but this discovery requires further confirmation and even though this was thought to be a variant of serotype 4, several studies have shown that rhesus macaque monkeys infected with the serotype 5 produced a different set of antibodies. Developing a tetravalent dengue vaccine that is both cost effective and safe has been a challenge for scientists 
Table 3. Progresses in dengue vaccine development in different companies

\begin{tabular}{|c|c|c|c|}
\hline Vaccine Name & Company & Phase of Clinical Trial & References \\
\hline Dengvaxia $^{\circledR}$ (CYD-TDV) & Sanofi Pasteur & III & {$[126,202]$} \\
\hline $\begin{array}{l}\text { Cell culture passage based live attenuated viruses } \\
\text { (Tetravalent vaccine) }\end{array}$ & $\begin{array}{l}\text { Walter Reed Army Institute of Research (WRAIR), } \\
\text { GlaxoSmithKline Biologicals }\end{array}$ & II & {$[203,204]$} \\
\hline $\begin{array}{l}\text { Yellow fever- DENV chimeric viruses (Tetravalent } \\
\text { vaccine) }\end{array}$ & $\begin{array}{l}\text { National Institutes of Health (NIH) and St. Louis } \\
\text { University Health Science Centre, Sanofi Pasteur }\end{array}$ & III & {$[205,206]$} \\
\hline $\begin{array}{l}\text { Mixture of cell culture passage based attenuated } \\
\text { virus and dengue-dengue intertypic chimeric } \\
\text { viruses (Tetravalent Vaccine) }\end{array}$ & Inviragen Inc. & II & {$[207,208]$} \\
\hline $\begin{array}{l}\text { Mixture of targeted mutagenesis based attenuated } \\
\text { viruses and dengue-dengue intertypic chimeric } \\
\text { viruses (Tetravalent vaccine) }\end{array}$ & $\begin{array}{l}\text { National Institute of Allergy and Infectious } \\
\text { Disease (NIAID), National Institutes of Health } \\
\text { (NIH), Butantan Institute }\end{array}$ & I & {$[209,210]$} \\
\hline $\begin{array}{l}\text { Purified inactivated dengue vaccine (Tetravalent } \\
\text { vaccine) }\end{array}$ & $\begin{array}{l}\text { Walter Reed Army Institute of Research (WRAIR), } \\
\text { GlaxoSmithKline Biologicals, Oswaldo Cruz } \\
\text { Foundation }\end{array}$ & 1 & [211] \\
\hline Recombinant subunit vaccine (Monovalent vaccine) & Merck and Co. & 1 & {$[208,212]$} \\
\hline $\begin{array}{l}\text { DNA vaccine expressing prM and E protein } \\
\text { (Monovalent vaccine) }\end{array}$ & $\begin{array}{l}\text { Naval Medical Research Centre, Walter Reed Army } \\
\text { Institute of Research (WRAIR) }\end{array}$ & I & [213] \\
\hline
\end{tabular}

Table 4. Phases of clinical trial

\begin{tabular}{lll}
\hline Phases of Clinical Trials & Sample size & Testing \\
\hline Phase I & $\begin{array}{ll}10-100 \text { people } \\
\text { Phase II }\end{array}$ & $\begin{array}{l}\text { To check whether it is safe for humans } \\
\text { The potency of the vaccine against artificial infection as well as vaccine safety, side effects and } \\
\text { immune response }\end{array}$ \\
$\begin{array}{ll}\text { Phase III } \\
\text { Phase IV }\end{array}$ & $\begin{array}{l}\text { The performance of the vaccine against natural infection } \\
\text { Large scale }\end{array}$ & Post marketing surveillance after the vaccine has been licensed and to find out rare side effects \\
\hline
\end{tabular}

all over the world and several potential vaccines are being tested after Mahidol University, Thailand and Walter Reed Army Institute of Research (USA) initiated the research [216,217]. Several other organizations such as Takeda Pharmaceuticals Company Limited, Bill \& Melinda Gates Foundation, The Global Health Innovative Technology (GHIT) Fund and many more have invested millions towards dengue research [218-221]. A study in Singapore confirmed that right after the infection, the immune cell called natural killer (NK) cells were activated in the blood and researchers hope that this knowledge may be beneficial while developing vaccines and drugs [222]. Moreover, another research team at University of California San Diego has synthetically engineered mosquitoes that will prevent the transmission of dengue virus by the activation of an antibody that prevents the replication of the virus and its dissemination [223]. Additionally, a study has shown that mutations in the protein envelope cause the dengue virus to change its shape and become resistant to vaccines and therapeutics [224].

Taking climate change into account for dengue research is important for the government and public health officials to take actions to protect the public from future dengue outbreaks. As the global climate changes, the global surface temperature will change and so will the patterns of rainfall around the world, affecting the environmental suitability for the survival and growth of dengue viruses and mosquitoes, which will eventually lead to the change in patterns of dengue globally, nationally, and locally. Having said that, several issues need to be taken into account during the research on DENV such as the sociodemographic factors e.g., travel and demographic change, and other climatic factors in some areas where temperature may not be the most vital aspect influencing the spread of dengue. Moreover, the non-climatic factors affecting the spread of $A$. aegypti and $A$. albopictus must also be explored [225]. Scientists have been investigating dengue pathogenesis in order to gain a better understanding of dengue infection. Improving surveillance of dengue cases by databases such as DengueNet that continuously updates and shares current and historical data on dengue cases by providing early warnings prior to epidemics can help improve the preparedness of public health officials, and help reduce fatality rates [226]. Many experts have said that dengue may increase in the future due to viral evolution, climate change, globalization, travel and trade. Settlement factors and socioeconomic factors also play a role in the spread of dengue. In light of this, it is important to follow the guidelines in WHO Global Strategy for Dengue Prevention and Control, 2012-2020 in order to prevent a huge outbreak as neither a perfect remedy nor a vaccine has been found yet [227].

\section{CONCLUSION}

Although, dengue outbreak is the most emerging global health threat in the 21st century, the adaptation of a successfully planned control program is the only preventive measure with no effective treatment options available. Some methods of prevention may include the use of insecticides, removal of mosquito vectors or the use of vaccines, mostly in the high burden epidemiologic areas. As a result, understanding of the pathogenesis and clinical symptoms is crucial for the implementation of proper preventive measures. Growth in population, frequent travels as well as urbanization has shown to affect the dengue epidemiology and thus the reemergence of the dengue epidemic. The increasing dengue outbreak along with no specific existing treatment for the disease makes much scientific efforts to be centered to secure therapeutic intervention. Rapid and more efficient dengue detection methods are required for an immediate approach 
towards early diagnosis of the infected patients. As the factors contributing to the spreading of dengue virus are increasing with the rise in globalization and climate change, the research for dengue vaccine and drug development requires more attention in order to prevent and prepare for further devastating outbreaks.

Author contributions: All authors have sufficiently contributed to the study, and agreed with the results and conclusions.

Funding: No funding source is reported for this study.

Declaration of interest: No conflict of interest is declared by authors.

Acknowledgements: Authors acknowledge the members of Swift Integrity Computational Lab, Dhaka, Bangladesh, a virtual platform of young researchers for their support during the preparation of the manuscript.

\section{REFERENCES}

1. Messina J, Brady O, Golding N, Kraemer M, Wint G, Ray S, et al. The current and future global distribution and population at risk of dengue. Nature Microbiology, 2019;4(9):1508-15. https://doi.org/10.1038/s41564-0190476-8 PMid:31182801 PMCid:PMC6784886

2. Chawla P, Yadav A, Chawla V. Clinical implications and treatment of dengue. Asian Pacific Journal of Tropical Medicine, 2014;7(3):169-78. https://doi.org/10.1016/S19957645(14)60016-X

3. Ebi KL, Nealon J. Dengue in a changing climate. Environmental research, 2016;151:115-23. https://doi.org/ 10.1016/j.envres.2016.07.026 PMid:27475051

4. Guzman M, Halstead S, Artsob H, Buchy P, Farrar J, Gubler $D$, et al. Dengue: a continuing global threat. Nature Reviews Microbiology, 2010;8(S12):S7-S16. https://doi.org/10.1038/ nrmicro2460 PMid:21079655 PMCid:PMC4333201

5. Nonyong $\mathrm{P}$, Pientong $\mathrm{C}$, Overgaard $\mathrm{H}$, Thaewnongiew $\mathrm{K}$, Aromseree $\mathrm{S}$, Phanitchat $\mathrm{T}$, et al. Correlation between dengue virus serotypes in dengue patients and in mosquitoes at patients' houses and surrounding in Northeastern Thailand. International Journal of Infectious Diseases, 2019;79:149. https://doi.org/10.1016/ j.ijid.2018.11.364

6. Bhatt S, Gething P, Brady O, Messina J, Farlow A, et al. The global distribution and burden of dengue. Nature, 2013; 496(7446):504-7. https://doi.org/10.1038/nature12060 PMid:23563266 PMCid:PMC3651993

7. Cunha B, Johnson D, McDermott B. Atypical Dengue Fever Mimicking Typhoid Fever in a College Student Traveler. The American Journal of Medicine, 2009;122(4):e1-e3. https://doi.org/10.1016/j.amjmed.2008.11.009 PMid:19332213

8. Günther J, Martínez-Muñoz J, Pérez-Ishiwara D, SalasBenito J. Evidence of Vertical Transmission of Dengue Virus in Two Endemic Localities in the State of Oaxaca, Mexico. Intervirology, 2007;50(5):347-52. https://doi.org/10.1159/ 000107272 PMid: 17700030

9. Guha-Sapir D, Schimmer B. Emerging Themes in Epidemiology, 2005;2(1):1. https://doi.org/10.1186/17427622-2-1 PMid:15743532 PMCid:PMC555563

10. Tuiskunen Bäck A, Lundkvist Å. Dengue viruses - an overview. 2020.

11. Waterman S, Gubler D. Dengue fever. Clinics in Dermatology, 1989;7(1):117-22. https://doi.org/10.1016/ 0738-081X(89)90034-5
12. Dengue: Dengue: Practice Essentials, Background, Pathophysiology. Emedicine.medscape.com. 2020. Available at: https://emedicine.medscape.com/article/ 215840-overview\#a2 (Accessed: 9 April 2020).

13. Rush B. An account of the bilious remitting fever. The American Journal of Medicine. 1951;11(5):546-50. https://doi.org/10.1016/0002-9343(51)90035-6

14. Nelson E, Bierman H. Dengue Fever: A Thrombocytopenic Disease?. JAMA, 1964;190(2). https://doi.org/10.1001/ jama.1964.03070150009002 PMid:14184528

15. Gubler D. Epidemic dengue/dengue hemorrhagic fever as a public health, social and economic problem in the 21st century. Trends in Microbiology, 2002;10(2):100-3. https://doi.org/10.1016/S0966-842X(01)02288-0

16. Gubler D, Clark G. Dengue/Dengue Hemorrhagic Fever: The Emergence of a Global Health Problem. Emerging Infectious Diseases, 1995;1(2):55-7. https://doi.org/10. 3201/eid0102.952004 PMid:8903160 PMCid:PMC2626838

17. Wilson M, Chen L. Dengue: Update on Epidemiology. Current Infectious Disease Reports, 2014;17(1). https://doi.org/10.1007/s11908-014-0457-2 PMid:25475383

18. Higa Y. Dengue Vectors and their Spatial Distribution. Tropical Medicine and Health, 2011;39(4SUPPLEMENT): S17-S27. https://doi.org/10.2149/tmh.2011-S04 PMid: 22500133 PMCid:PMC3317606

19. Carrington L, Simmons C. Human to Mosquito Transmission of Dengue Viruses. Frontiers in Immunology. 2014;5. https://doi.org/10.3389/fimmu.2014.00290

20. Kyle J, Harris E. Global Spread and Persistence of Dengue. Annual Review of Microbiology, 2008;62(1):71-92. https://doi.org/10.1146/annurev.micro.62.081307.163005 PMid:18429680

21. Yin $X$, Zhong $X$, Pan S. Vertical transmission of dengue infection: the first putative case reported in China. 2020.

22. Basurko C, Matheus S, Hildéral H, Everhard S, Restrepo M, Cuadro-Alvarez $E$ et al. Estimating the Risk of Vertical Transmission of Dengue: A Prospective Study. The American Journal of Tropical Medicine and Hygiene, 2018;98(6):1826-1832. https://doi.org/10.4269/ajtmh.160794 PMid:29692297 PMCid:PMC6086150

23. Guzman M, Gubler D, Izquierdo A, Martinez E, Halstead S. Dengue infection. Nature Reviews Disease Primers, 2016;2(1). https://doi.org/10.1038/nrdp.2016.55 PMid: 27534439

24. Martina B, Koraka P, Osterhaus A. Dengue Virus Pathogenesis: an Integrated View. Clinical Microbiology Reviews, 2009;22(4):564-81. https://doi.org/10.1128/ CMR.00035-09 PMid:19822889 PMCid:PMC2772360

25. Diamond M. Evasion of innate and adaptive immunity by flaviviruses. Immunology and Cell Biology, 2003;81(3):196206. https://doi.org/10.1046/j.1440-1711.2003.01157.x PMid:12752684

26. Dengue virus replication | Learn Science at Scitable. Nature.com. 2020. Available at: https://www.nature.com/ scitable/content/dengue-virus-replication-22401525/ (Accessed: 9 April 2020).

27. Daep C, Muñoz-Jordán J, Eugenin E. Flaviviruses, an expanding threat in public health: focus on dengue, West Nile, and Japanese encephalitis virus. Journal of NeuroVirology, 2014;20(6):539-60. https://doi.org/10.1007/ s13365-014-0285-z PMid:25287260 PMCid:PMC4331079 
28. Mukhopadhyay S, Kuhn R, Rossmann M. A structural perspective of the flavivirus life cycle. Nature Reviews Microbiology, 2005;3(1):13-22. https://doi.org/10.1038/ nrmicro1067 PMid:15608696

29. Clyde K, Kyle J, Harris E. Recent Advances in Deciphering Viral and Host Determinants of Dengue Virus Replication and Pathogenesis. Journal of Virology, 2006;80(23):1141831. https://doi.org/10.1128/JVI.01257-06 PMid:16928749 PMCid:PMC1642597

30. Takahashi H, Suzuki Y. Cellular Control of Dengue Virus Replication: Role of Interferon-Inducible Genes. Dengue Immunopathology and Control Strategies. 2017. https://doi.org/10.5772/67984

31. Pokhrel P. Replication of Dengue Virus - Microbiology Notes. Microbiology Notes. 2020. Available at: https://microbiologynotes.com/replication-of-denguevirus/ (Accessed: 11 April 2020).

32. Byk L, Gamarnik A. Properties and Functions of the Dengue Virus Capsid Protein. Annual Review of Virology, 2016;3(1):263-81. https://doi.org/10.1146/annurevvirology-110615-042334 PMid:27501261 PMCid: PMC5417333

33. Alcaraz-Estrada S, Yocupicio-Monroy M, del Angel R. Insights into dengue virus genome replication. Future Virology, 2010;5(5):575-92. https://doi.org/10.2217/ fvl.10.49

34. Dengue Transmission | Learn Science at Scitable. Nature.com. 2020. Available at: https://www.nature.com/ scitable/topicpage/dengue-transmission-22399758/ (Accessed: 9 April 2020).

35. Guzmán M, Kouri G, Bravo J, Valdes L, Susana V, Halstead S. Effect of age on outcome of secondary dengue 2 infections. International Journal of Infectious Diseases, 2002;6(2):118 124. https://doi.org/10.1016/S1201-9712(02)90072-X

36. Guzmán M, Kourí G, Valdés L, Bravo J, Vázquez S, Halstead S. Enhanced severity of secondary dengue-2 infections: death rates in 1981 and 1997 Cuban outbreaks. Revista Panamericana de Salud Pública, 2002;11(4):223-227. https://doi.org/10.1590/S1020-49892002000400003 PMid:12049030

37. Halstead S, Sun W, Kanesa-Thasan N, Russell K, Putvatana $R$, Streit T et al. Haiti: absence of dengue hemorrhagic fever despite hyperendemic dengue virus transmission. The American Journal of Tropical Medicine and Hygiene, 2001;65(3):180-3. https://doi.org/10.4269/ajtmh.2001.65. 180 PMid: 11561700

38. Balmaseda A, Silva S, Cuadra R, Perez M, Mercado J, Hammond S, et al. Serotype-specific differences in clinical manifestations of dengue. The American Journal of Tropical Medicine and Hygiene, 2006;74(3):449-56. https://doi.org/10.4269/ajtmh.2006.74.449 PMid:16525106

39. Messer W, Gubler D, Harris E, Sivananthan K, de Silva A. Emergence and Global Spread of a Dengue Serotype 3, Subtype III Virus. Emerging Infectious Diseases, 2003;9(7):800-9. https://doi.org/10.3201/eid0907.030038 PMCid:PMC3023445

40. Rico-Hesse R, Harrison L, Salas R, Tovar D, Nisalak A, Ramos $C$, et al. Origins of Dengue Type 2 Viruses Associated with Increased Pathogenicity in the Americas. Virology, 1997;230(2):244-51. https://doi.org/10.1006/viro.1997.8504 PMid:9143280
41. Burke D, Scott R, Johnson D, Nisalak A. A Prospective Study of Dengue Infections in Bangkok. The American Journal of Tropical Medicine and Hygiene, 1988;38(1):172-80. https://doi.org/10.4269/ajtmh.1988.38.172 PMid:3341519

42. Navarro-Sánchez E, Desprès $P$, Cedillo-Barrón L. Innate Immune Responses to Dengue Virus. Archives of Medical Research, 2005;36(5):425-35. https://doi.org/10.1016/ j.arcmed.2005.04.007 PMid:16099317

43. Costa V, Fagundes C, Souza D, Teixeira M. Inflammatory and Innate Immune Responses in Dengue Infection. The American Journal of Pathology, 2013;182(6):1950-61. https://doi.org/10.1016/j.ajpath.2013.02.027 PMid:23567637

44. St. John A, Rathore A. Adaptive immune responses to primary and secondary dengue virus infections. Nature Reviews Immunology, 2019;19(4):218-30. https://doi.org/ 10.1038/s41577-019-0123-x PMid:30679808

45. Taweechaisupapong S, Sriurairatana S, Angsubhakorn S, Yoksan S, Bhamarapravati N. In vivo and in vitro studies on the morphological change in the monkey epidermal Langerhans cells following exposure to dengue 2 (16681) virus. Southeast Asian J Trop Med Public Health, 1996;27:664-72.

46. Taweechaisupapong S, Sriurairatana S, Angsubhakorn S, Yoksan S, Khin MM, Sahaphong S, Bhamarapravati N. Langerhans cell density and serological changes following intradermal immunisation of mice with dengue 2 virus. J Med Microbiol, 1996;45:138-45. https://doi.org/10.1099/ 00222615-45-2-138 PMid:8683550

47. Moi M, Takasaki T, Kurane I. Human antibody response to dengue virus: implications for dengue vaccine design. Tropical Medicine and Health, 2016;44(1). https://doi.org/10.1186/s41182-016-0004-y PMid:27398060 PMCid:PMC4934144

48. Schmid M, Diamond M, Harris E. Dendritic Cells in Dengue Virus Infection: Targets of Virus Replication and Mediators of Immunity. Frontiers in Immunology, 2014;5. https://doi.org/10.3389/fimmu.2014.00647 PMid:25566258 PMCid:PMC4269190

49. Yam-Puc J, Cedillo-Barrón L, Aguilar-Medina E, RamosPayán R, Escobar-Gutiérrez A, Flores-Romo L. The Cellular Bases of Antibody Responses during Dengue Virus Infection. Frontiers in Immunology, 2016;7. https://doi.org/10.3389/fimmu.2016.00218

50. Halstead SB. Dengue hemorrhagic fever: Two infections and antibody dependent enhancement, a brief history and personal memoir. Revista Cubana de Medicina Tropical, 2002;54:171-179.

51. Halstead SB. Pathogenesis of dengue: challenges to molecular biology. Science, 1988;239:476-8. https://doi.org /10.1126/science.239.4839.476 PMid:3277268

52. Halstead SB. Dengue hemorrhagic fever. Trans R Soc Trop Med Hyg, 1983;77:739. https://doi.org/10.1016/00359203(83)90219-5

53. Halstead SB, O'Rourke EJ. Dengue viruses and mononuclear phago-cytes. I. Infection enhancement by non-neutralizing antibodies. J Exp Med, 1977;146:201-17. https://doi.org/10.1084/jem.146.1.201 PMid:406347 PMCid: PMC2180729

54. Halstead SB, O'Rourke EJ. Antibody-enhanced dengue virus infection in primate leukocytes. Nature, 1977;265:73941. https://doi.org/10.1038/265739a0 PMid:404559 
55. Wahala W, de Silva A. The Human Antibody Response to Dengue Virus Infection. Viruses, 2011;3(12):2374-95. https://doi.org/10.3390/v3122374 PMid:22355444 PMCid: PMC3280510

56. Halstead SB. Neutralization and antibody-dependent enhancement of dengue viruses. Adv. Virus Res., 2003;60:421-67. https://doi.org/10.1016/S00653527(03)60011-4

57. Beltramello $M$, Williams K, Simmons C, Macagno A, Simonelli L, Quyen $N$ et al. The Human Immune Response to Dengue Virus Is Dominated by Highly Cross-Reactive Antibodies Endowed with Neutralizing and Enhancing Activity. Cell Host \& Microbe, 2010;8(3):271-83. https://doi.org/10.1016/j.chom.2010.08.007 PMid:20833378 PMCid:PMC3884547

58. Whitehead S, Blaney J, Durbin A, Murphy B. Prospects for a dengue virus vaccine. Nature Reviews Microbiology, 2007;5(7):518-28. https://doi.org/10.1038/nrmicro1690 PMid: 17558424

59. Ho T, Wang S, Anderson R, Liu C. Antibodies in dengue immunopathogenesis. Journal of the Formosan Medical Association, 2013;112(1):1-2. https://doi.org/10.1016/ j.jfma.2012.11.009 PMid:23332422

60. Wan S, Lin C, Yeh T, Liu C, Liu H, Wang S et al. Autoimmunity in dengue pathogenesis. Journal of the Formosan Medical Association, 2013;112(1):3-11. https://doi.org/10.1016/ j.jfma.2012.11.006 PMid:23332423

61. Kliks SC, Nisalak A, Brandt WE, Wahl L, Burke DS. Antibodydependent enhancement of dengue virus growth in human monocytes as a risk factor for dengue hemorrhagic fever. Am J Trop Med Hyg., 1989;40:444-51. https://doi.org/ 10.4269/ajtmh.1989.40.444 PMid:2712199

62. Kliks SC, Nimmanitya S, Nisalak A, Burke DS. Evidence that maternal dengue antibodies are important in the development of dengue hemorrhagic fever in infants. Am J Trop Med Hyg., 1988;38:411-9. https://doi.org/10.4269/ ajtmh.1988.38.411 PMid:3354774

63. Srikiatkhachorn, A., Mathew, A. and Rothman, A.L., 2017, July. Immune-mediated cytokine storm and its role in severe dengue. In Seminars in immunopathology (Vol. 39, No. 5, pp. 563-574). Springer Berlin Heidelberg. https://doi.org/10.1007/s00281-017-0625-1 PMid:28401256 PMCid:PMC5496927

64. Rathore A, St. John A. Immune responses to dengue virus in the skin. Open Biology, 2018;8(8):180087. https://doi.org/ 10.1098/rsob.180087 PMid:30135238 PMCid:PMC6119867

65. Sanyaolu A. Global Epidemiology of Dengue Hemorrhagic Fever: An Update. Journal of Human Virology \& Retrovirology, 2017;5(6). https://doi.org/10.15406/jhvrv. 2017.05.00179

66. Kularatne SA. Dengue fever. Bmj, 2015;351:h4661. https://doi.org/10.1136/bmj.h4661 PMid:26374064

67. Whitehorn J, Farrar J. Dengue. British Medical Bulletin. 2010;95(1):161-73. https://doi.org/10.1093/bmb/ldq019 PMid:20616106

68. Gubler D. The changing epidemiology of yellow fever and dengue, 1900 to 2003: full circle? Comparative Immunology, Microbiology and Infectious Diseases, 2004 Sep;27(5):319-30. https://doi.org/10.1016/j.cimid.2004.03. 013 PMid: 15225982

69. Kalayanarooj S. Clinical Manifestations and Management of Dengue/DHF/DSS. Tropical Medicine and Health, 2011;39(4SUPPLEMENT):S83-S87. https://doi.org/10.2149/ tmh.2011-S10 PMid:22500140 PMCid:PMC3317599
70. Comprehensive guidelines for prevention and control of dengue and dengue haemorrhagic fever. New Delhi, India: World Health Organization Regional Office for South-East Asia; 2011.

71. Heilman JM, De Wolff J, Beards GM, Basden BJ. Dengue fever: A Wikipedia clinical review. Open Med., 2014;8(4):e105-e115.

72. Muller D, Depelsenaire A, Young P. Clinical and Laboratory Diagnosis of Dengue Virus Infection. The Journal of Infectious Diseases, 2017;215(suppl_2):S89-S95. https://doi.org/10.1093/infdis/jiw649 PMid:28403441

73. Rathnasiri Bandara SM, et al. Management of Dengue and Post Dengue Complication Syndrome: A Review. Acta Scientific Microbiology, 2.4(2019):22-9.

74. Simmons C, Farrar J, van Vinh Chau N, Wills B. Dengue. New England Journal of Medicine, 2012;366(15):1423-32. https://doi.org/10.1056/NEJMra1110265 PMid:22494122

75. Rigau-Pérez JG, Clark GG, Gubler DJ, Reiter P, Sanders EJ, Vorndam AV. Dengue and dengue haemorrhagic fever. Lancet, 1998;352:971-7. https://doi.org/10.1016/S01406736(97)12483-7

76. Kalayanarooj S, Vaughn DW, Nimmannitya S, et al. Early clinical and laboratory indicators of acute dengue illness. J Infect Dis, 1997;176:313-21. https://doi.org/10.1086/ 514047 PMid:9237695

77. Chen L, Wilson M. Dengue and chikungunya infections in travelers. Current Opinion in Infectious Diseases, 2010;23(5):438-44. https://doi.org/10.1097/QCO.0b013e32 833c1d16 PMid:20581669

78. Dengue Guidelines for Diagnosis Treatment Prevention and Control. World Health Organization; 2009.

79. Wolff K, Johnson R, Fitzpatrick T. Fitzpatrick's color atlas and synopsis of clinical dermatology. New York: McGrawHill Medical; 2009.

80. Kalayanarooj S, Vaughn D, Nimmannitya S, Green S, Suntayakorn S, Kunentrasai $\mathrm{N}$ et al. Early Clinical and Laboratory Indicators of Acute Dengue Illness. The Journal of Infectious Diseases, 1997;176(2):313-21. https://doi.org/10.1086/514047 PMid:9237695

81. Ranjit S, Kissoon N. Dengue hemorrhagic fever and shock syndromes ${ }^{*}$ Pediatric Critical Care Medicine, 2011;12(1):90-100. https://doi.org/10.1097/PCC.0b013e31 81e911a7 PMid:20639791

82. Sun P, Kochel T. The Battle between Infection and Host Immune Responses of Dengue Virus and Its Implication in Dengue Disease Pathogenesis. The Scientific World Journal, 2013;2013:1-11. https://doi.org/10.1155/2013/ 843469

83. Halstead SB. Observations related to pathogenesis of dengue hemorrhagic fever. VI. Hypotheses and discussion. Yale J. Biol. Med., 1970;42:350-62.

84. Lum LCS, Ng CJ, Khoo EM. Managing dengue fever in primary care: A practical approach. Malays Fam Physician, 2014;9(2):2-10.

85. Kuo H, Lee I, Liu J. Analyses of clinical and laboratory characteristics of dengue adults at their hospital presentations based on the World Health Organization clinical-phase framework: Emphasizing risk of severe dengue in the elderly. Journal of Microbiology, Immunology and Infection, 2018;51(6):740-8. https://doi.org/10.1016/j.jmii.2016.08.024 PMid:28734676 
86. Jayadas T, Kumanan T, Arasaratnam V, Gajapathy K, Surendran S. The clinical profile, hematological parameters and liver transaminases of dengue NS1 Ag positive patients admitted to Jaffna Teaching Hospital, Sri Lanka. BMC Research Notes, 2019;12(1). https://doi.org/10.1186/s13104-019-4655-8

PMid:31547852 PMCid:PMC6755686

87. World Health Organization. Prevention and control of dengue and dengue haemorrhagic fever. WHO Regional Office for South-East Asia; 1999.

88. Pongpan S, Wisitwong A, Tawichasri C, Patumanond J. Prognostic indicators for dengue infection severity. International Journal of Clinical Pediatrics, 2013 Jun 16;2(1):12-8. https://doi.org/10.1155/2013/845876 PMid: 24324896 PMCid:PMC3845515

89. World Health Organization. Dengue hemorrhagic fever: diagnosis, treatment, prevention and control. Geneva: WHO, 1997.

90. Chagan-Yasutan H, Ndhlovu L, Lacuesta T, Kubo T, Leano $P$, Niki $T$, et al. Galectin-9 plasma levels reflect adverse hematological and immunological features in acute dengue virus infection. Journal of Clinical Virology, 2013;58(4):635-40.

https://doi.org/10.1016/j.jcv.2013.10.022

91. Soe H, Yong Y, Al-Obaidi M, Raju C, Gudimella R, Manikam $\mathrm{R}$ et al. Identifying protein biomarkers in predicting disease severity of dengue virus infection using immunerelated protein microarray. Medicine, 2018;97(5):e9713. http://dx.doi.org/10.1097/MD.0000000000009713

92. Lima W, Souza N, Fernandes S, Cardoso V, Godói I. Serum lipid profile as a predictor of dengue severity: A systematic review and meta-analysis. Reviews in Medical Virology, 2019;29(5). https://doi.org/10.1002/rmv.2056 PMid: 31172625

93. Kalayanarooj S. Standardized clinical management: evidence of reduction of dengue hemorrhagic fever casefatality rate in Thailand. Dengue Bulletin, 1999;23:10-16.

94. Kalayanarooj S, Rothman A, Srikiatkhachorn A. Case Management of Dengue: Lessons Learned. The Journal of Infectious Diseases, 2017;215(suppl_2):S79-S88. https://doi.org/10.1093/infdis/jiw609 PMid:28403440 PMCid:PMC5853291

95. Hung N. Fluid management for dengue in children. Paediatrics and International Child Health, 2012;32(sup1):39-42. https://doi.org/10.1179/204690471 2Z.00000000051 PMid:22668449 PMCid:PMC3381450

96. Kaur P, Kaur G. Transfusion support in patients with dengue fever. International Journal of Applied and Basic Medical Research, 2014;4(3):8. https://doi.org/10.4103/ 2229-516X.140708 PMid:25298950 PMCid:PMC4181139

97. World Health Organization, UNICEF. Handbook for clinical management of dengue. Available at: https://scholar. google.com/scholar?hl=en\&as_sdt=0\%2C5\&q=medical+o fficers+Handbook+for+clinical+management+of+dengue. \&btnG=\#d=gs_qabs\&u=\%23p\%3DitdRkRrm4fs J

98. Guidelines on Management of Dengue Fever \& Dengue Haemorrhagic Fever in Adults. Ministry of Health - Sri Lanka. 2012.

99. Nhan N, Phuong C, Kneen R, Wills B, Van My N, Phuong N et al. Acute Management of Dengue Shock Syndrome: A Randomized Double-Blind Comparison of 4 Intravenous Fluid Regimens in the First Hour. Clinical Infectious Diseases, 2001;32(2):204-13. https://doi.org/10.1086/ 318479 PMid:11170909
100. World Health Organization, Regional Office for South-East Asia. Guidelines for treatment of dengue fever/dengue haemorrhagic fever in small hospitals. WHO Regional Office for South-East Asia. 1999. Available at: https://apps.who.int/iris/handle/10665/205177

101. Rajapakse S, Rodrigo C, Rajapakse. Treatment of dengue fever. Infection and Drug Resistance, 2012;103. https://doi.org/10.2147/IDR.S22613 PMid:22870039 PMCid:PMC3411372

102. Prasert Thongcharoen. Monograph on dengue/dengue haemorrhagic fever. New Delhi: World Health Organization, Regional Office for South-East Asia; 1993.

103. Guzman MG, Kouri G. Dengue: an update. Lancet Infect Dis, 2002;2:33-42. 3099(01)00171-2

104. Mutsuddy P, Tahmina Jhora S, Shamsuzzaman A, Kaisar S, Khan M. Dengue Situation in Bangladesh: An Epidemiological Shift in terms of Morbidity and Mortality. Canadian Journal of Infectious Diseases and Medical Microbiology, 2019;2019:1-12. https://doi.org/10.1155/ 2019/3516284 PMid:30962860 PMCid:PMC6431455

105. Shepard DS, Undurraga EA, Halasa YA. Economic and disease burden of dengue in Southeast Asia. PLOS: Neglected Tropical Diseases, 2013;7(2):e2055. https://doi.org/10.1371/journal.pntd.0002055 PMid:23437406 PMCid:PMC3578748

106. WHO. Scientific Working Group Report on Dengue Available at: http://apps.who.int/tdr/publications/tdrresearch-publications/swg-reportdengue/pdf/swg_ dengue_2.pdf

107. TDR/WHO. Dengue: Guidelines for Diagnosis, Treatment, Prevention and Control (TDR/WHO, Geneva, Switzerland, 2009).

108. Howe GM. A World geography of human diseases. New York: Academic Press, 1977. p. 302-17.

109. Gubler DJ. Dengue and dengue haemorrhagic fever: its history and resurgence as a global public health problem. In: Gubler DJ, Kuno G. Eds. Dengue and dengue haemorrhagic fever. Wallingford, Oxon: CAB international, 1997. p. 1-22. https://doi.org/10.1079/9781845939649. 0001

110. Schaffner F, Mathis A. Dengue and dengue vectors in the WHO European region: past, present, and scenarios for the future. Lancet Infect Dis., 2014;14(12):1271-80. https://doi.org/10.1016/S1473-3099(14)70834-5

111. Gubler DJ. The changing epidemiology of yellow fever and dengue, 1900 to 2003: full circle? Comp. Immunol. Microbiol. Infect. Dis., 2004;27:319-30. https://doi.org/ 10.1016/j.cimid.2004.03.013 PMid:15225982

112. Wilder-Smith A. Dengue in travelers. New Engl. J. Med., 2005;353:924-32. https://doi.org/10.1056/NEJMra041927 PMid:16135837

113. Freedman DO, et al. Spectrum of disease and relation to place of exposure among ill returned travelers. New Engl. J. Med., 2006;354:119-30. https://doi.org/10.1056/ NEJMoa051331 PMid:16407507

114. Wichmann O. Dengue antibody prevalence in German travelers. Emerg. Infect. Dis. 11, 762-765 (2005).9. Jelinek, T. Dengue fever in international travelers. Clin. Infect. Dis., 2000;31:144-7. https://doi.org/10.3201/eid1105.050097 PMid:15890135 PMCid:PMC3320360 
115. Swain S, Bhatt M, Pati S, et al. Distribution of and associated factors for dengue burden in the state of Odisha, India during 2010-2016. Infect Dis Poverty, 2019;8:31. https://doi.org/10.1186/s40249-019-0541-9 PMid:31056077 PMCid:PMC6501402

116. Wilder-Smith A, Murray, Quam M. Epidemiology of dengue: past, present and future prospects. 2013. https://doi.org/10.2147/CLEP.S34440 PMid:23990732 PMCid:PMC3753061

117. Ooi E. Gubler Dengue in Southeast Asia: epidemiological characteristics and strategic challenges in disease prevention. Cadernos de Saúde Pública, 2009;25(suppl 1):S115-S124. https://doi.org/10.1590/S0102311X2009001300011 PMid:19287856

118. The dengue situation in Singapore. Epidemiol Bull 1994;20:31-3.

119. Russel PK, Busescher EL, McCown JM, Ordonez J. Recovery of dengue viruses from patients during epidemics in Puerto Rico and East Pakistan. American Journal of Tropical Medicine and Hygiene, 1966;15(4):573-9. https://doi.org/10.4269/ajtmh.1966.15.573 PMid:4957424

120. Amin MMM, Hussain AMZ, Nahar K, Chowdhury IA, Murshed $M$, Chowdhury SA. Sero-diagnosis of dengue infections in four metropolitan cities of Bangladesh. Dengue Bulletin, 2000;24:29-33.

121. Guo C, Zhou Z, Wen Z, Liu Y, Zeng C, Xiao D et al. Global Epidemiology of Dengue Outbreaks in 1990-2015: A Systematic Review and Meta-Analysis. Frontiers in Cellular and Infection Microbiology, 2017;7. https://doi.org/10.3389/fcimb.2017.00317 PMid:28748176 PMCid:PMC5506197

122. Sharmin S, Viennet E, Glass K, Harley D. The emergence of dengue in Bangladesh: epidemiology, challenges and future disease risk. Transactions of The Royal Society of Tropical Medicine and Hygiene, 2015;109(10):619-27. https://doi.org/10.1093/trstmh/trv067 PMid:26333430

123. Hsan K, Hossain M, Sarwar M, Wilder-Smith A, Gozal D. Unprecedented rise in dengue outbreaks in Bangladesh. The Lancet Infectious Diseases, 2019;19(12):1287. https://doi.org/10.1016/S1473-3099(19)30616-4

124. More bad news: Dengue is back too. Dhaka Tribune. 2020. Available at: https://www.dhakatribune.com/bangladesh/ 2020/04/01/dengue-outbreak-looms-no-room-forcomplacency (Accessed: 15 June 2020).

125. Page F, Alam H. Rise in dengue cases rings alarm. The Daily Star. 2020 Available at: https://www.thedailystar.net/ frontpage/news/rise-dengue-cases-rings-alarm-1881676

126. World Health Organization. Update on the Dengue situation in the Western Pacific Region. Dengue Situation Update Number $594 . \quad$ Available at: https://iris.wpro.who.int/bitstream/handle/10665.1/1446 1/Dengue-20200102.pdf

127. World Health Organization. Update on the Dengue situation in the Western Pacific Region. Dengue Situation Update Number $595 . \quad$ Available at: https://www.who.int/docs/default-source/wpro--documents/emergency/surveillance/dengue/dengue20200326.pdf?sfvrsn=5160e027_24

128. Brathwaite Dick O, San Martín J, del Diego J, Montoya R, Dayan G, Zambrano B. The History of Dengue Outbreaks in the Americas. The American Journal of Tropical Medicine and Hygiene, 2012;87(4):584-93. https://doi.org/10.4269/ ajtmh.2012.11-0770 PMid:23042846 PMCid:PMC3516305
129. Introduction to International Disaster Management. Google Books. 2020. Available at: https://books.google. com.bd/books?id=m2KP3qbY1aUC\&pg=PA230\&lpg=PA23 $0 \& d q=i n+1981+d e n+4+a n d+a n o t h e r+s t r a i$

130. World Health Organization. Dengue and severe dengue. Available at: https://www.who.int/news-room/factsheets/detail/dengue-and-severe-dengue

131. Who.int. 2020. Available at: https://www.who.int/docs/ default-source/wpro---documents/emergency/surve illance/dengue/dengue-20200227.pdf?sfvrsn=fc80101d_ 30 (Accessed: 11 April 2020).

132. Lumley GF. Dengue. Part 1. Medical. In: Lumley GF, Taylor $\mathrm{FH}$ (eds) Dengue. Service Publication (School of Public Health and Tropical Medicine) No. 3. Sydney, University of Sydney and Commonwealth Department of Health. 1942: 9-142.

133. Russell RC, Lee DJ, Stanislas Y. Aedes aegypti (L.) (Diptera: Culicidae) in New South Wales. Gen ApplEntomol 1984;16.

134. Whelan PI. The Northern Territory remains full of dengue fever vectors. Bull Mosq Cont Assoc Aust, 1991;3:1-6.

135. McLean DM, Magrath WJ. Dengue in the Northern Territory. Med J Australia, 1959;46:719-21. https://doi.org/10.5694/ j.1326-5377.1959.tb129466.x

136. Kay BH, Marks EN, Barker-Hudson P. Dengue in Queensland, Australia 198 1-83. Proceedings of the International Conference on Dengue and Dengue Haemorrhagic Fever, Kuala Lumpur, Malaysia. Sept. 1983;110-23.

137. Sinclair DP. The distribution of Aedes aegypti in Queensland, 1990 to 30 June 1992. Comm Dis Intell (Aust) 1992;16:400-3.

138. Lee DJ, Hicks MM, Griffiths M, et al. The Culicidae of the Australasian Region, vol. 4. Canberra, Australian Government Publishing Service. 1987.

139. Hanna JN, Ritchie SA, Richards AR, Humphreys JL, Montgomery BL, Ehlers GJ, Pyke AT, Taylor CT. Dengue in north Queensland, 2005-2008. Communicable diseases intelligence quarterly report, 2009 Jun;33(2):198.

140. Mitchell C. PAHO/WHO | Cases of dengue in the Americas exceeded 3 million in 2019. Pan American Health Organization / World Health Organization. 2020. Available at: https://www.paho.org/hq/index.php?option=com content\&view=article\&id=15722: cases-of-dengue-in-theamericas-exceeded-3-million-in-2019\&ltemid=1926\&lang =en (Accessed: 11 April 2020).

141. Louis C. Daily Newspaper View of Dengue Fever Epidemic, Athens, Greece, 1927-1931. Emerging Infectious Diseases, 2012;18(1):78-82. https://doi.org/10.3201/eid1801.110191 PMid:22257469 PMCid:PMC3310089

142. Dengue in the WHO European Region - World Health Organization. Available at: http://www.euro.who.int/__ data/assets/pdf_file/0009/234198/Dengue-in-the-WHOEuropean-Region.pdf

143. Rapid risk assessment: Dengue outbreak in Réunion, France, and associated risk of autochthonous outbreak in the EU/EEA. European Centre for Disease Prevention and Control. 2020. Available at: https://www.ecdc.europa. eu/en/publications-data/rapid-risk-assessment-dengueoutbreak-reunion-france-and-associated-risk

144. Rogers DJ, Hay SI, Suk J, Semenza J, Zeller H. The climatic suitability for dengue transmission in continental Europe. European Centre for Disease Prevention and Control; 2012. 
145. WHO T. Dengue: guidelines for diagnosis, treatment, prevention and control. Geneva: WHO Library. 2009 Sep:10-2.

146. Centers for Disease Control and Prevention. Laboratory guidance and diagnostic testing. Centers for Disease Control and Prevention, Atlanta, GA. 2012. Available at: http://www.cdc.gov/dengue/clinicalLab/laboratory.html

147. Luo R, Fongwen N, Kelly-Cirino C, Harris E, Wilder-Smith A, Peeling R. Rapid diagnostic tests for determining dengue serostatus: a systematic review and key informant interviews. Clinical Microbiology and Infection, 2019;25(6):659-66. https://doi.org/10.1016/j.cmi.2019.01. 002 PMid:30664935 PMCid:PMC6543064

148. Wai MN. Revisiting the approach to dengue: the primary care perspective. The Singapore Family Physician, 2015 Jul 1;41(2):65-73.

149. Peeling R, Artsob H, Pelegrino J, Buchy P, Cardosa M, Devi $S$, et al. Evaluation of diagnostic tests: dengue. Nature Reviews Microbiology, 2010;8(S12):S30-S37. https://doi.org/10.1038/nrmicro2459 PMid:21548185

150. Dengue Virus Antigen Detection / Dengue | CDC. Cdc.gov. 2019. Available at: https://www.cdc.gov/dengue/ healthcare-providers/testing/antigen-detection.html (Accessed: 11 May 2020).

151. Rainwater-Lovett K, Rodriguez-Barraquer I, Cummings D, Lessler J. Variation in dengue virus plaque reduction neutralization testing: systematic review and pooled analysis. BMC Infectious Diseases. 2012;12(1):233. https://doi.org/10.1186/1471-2334-12-233 PMid:23020074 PMCid:PMC3519720

152. Eivazzadeh-Keihan R, Pashazadeh-Panahi P, Mahmoudi T, Chenab K, Baradaran B, Hashemzadeh M et al. Dengue virus: a review on advances in detection and trends - from conventional methods to novel biosensors. Microchimica Acta. 2019;186(6). https://doi.org/10.1007/s00604-0193420-y PMid:31055654

153. Roehrig JT, Hombach J, Barrett AD. Guidelines for plaquereduction neutralization testing of human antibodies to dengue viruses. Viral immunology, 2008 Jun 1;21(2):12332. https://doi.org/10.1089/vim.2008.0007 PMid:18476771

154. Sasmono RT, Aryati A, Wardhani P, Yohan B, Trimarsanto $\mathrm{H}$, Fahri $\mathrm{S}$, et al. Performance of Simplexa dengue molecular assay compared to conventional and SYBR green RT-PCR for detection of dengue infection in Indonesia. PLoS One, 2014;9:e103815. https://doi.org/ 10.1371/journal.pone.0103815 PMid:25102066 PMCid: PMC4125142

155. Limonta D, Falcón V, Torres G, Capó V, Menéndez I, Rosario $D$, et al. Dengue virus identification by transmission electron microscopy and molecular methods in fatal dengue hemorrhagic fever. Infection, 2012;40(6):689-94. https://doi.org/10.1007/s15010-012-0260-7 PMid:22527878

156. Eivazzadeh-Keihan R, Pashazadeh-Panahi P, Baradaran B, de la Guardia M, Hejazi M, Sohrabi H, et al. Recent progress in optical and electrochemical biosensors for sensing of Clostridium botulinum neurotoxin. Trends Anal Chem, 2018;103:184-97. https://doi.org/10.1016/j.trac.2018.03.019

157. Kamil YM, Bakar MA, Mustapa M, Yaacob M, Abidin N, Syahir A, et al. Label-free dengue E protein detection using a functionalized tapered optical fiber sensor. Sensors Actuators B Chem, 2018;257:820-8. https://doi.org/ 10.1016/j.snb.2017.11.005
158. Santos A, Bueno PR, Davis JJ. A dual marker label free electrochemical assay for Flavivirus dengue diagnosis. Biosens Bioelectron, 2018;100:519-25. https://doi.org/ 10.1016/j.bios.2017.09.014 PMid:28985612

159. Goddard JM, Mandal S, Nugen SR, Baeumner AJ, Erickson D. Biopatterning for label-free detection. Colloids Surf B Biointerfaces, 2010;76:375-80. https://doi.org/10.1016/ j.colsurfb.2009.10.041 PMid:19939644 PMCid:PMC2818543

160. Huang MC, Mateus CF, Foley JE, Beatty R, Cunningham BT, Chang-Hasnain CJ. VCSEL optoelectronic biosensor for detection of infectious diseases. IEEE Photon Technol Lett, 2008;20:443-5. https://doi.org/10.1109/LPT.2008.916947

161. Carrillo C, Werbajh S, Malnero C, Stolowicz F, Larocca L, Malirat V, et al. Development of a colorimetric RT-LAMP amplification assay adapted to an early and easy detection of dengue virus. Int J Infect Dis, 2018;73:171. https://doi.org/10.1016/j.ijid.2018.04.3801

162. Rahman SA, Saadun R, Azmi NE, Ariffin N, Abdullah J, Yusof $N A$, et al. Label-free dengue detection utilizing PNA/DNA hybridization based on the aggregation process of unmodified gold nanoparticles. J Nanomater, 2014:106. https://doi.org/10.1155/2014/839286

163. Fu C, Gu Y, Wu Z, Wang Y, Xu S, Xu W. Surface Enhanced Raman scattering (SERS) biosensing based on nanoporous dielectric waveguide resonance. Sensors Actuators B Chem, 2014;201:173-6. https://doi.org/10.1016/j.snb.2014. 04.091

164. Ngo HT, Wang H-N, Fales AM, Nicholson BP, Woods CW, VoDinh T. DNA bioassay-on-chip using SERS detection for dengue diagnosis. Analyst, 2014;139:5655-9. https://doi.org/10.1039/C4AN01077A PMid:25248522

165. Moran K, Lemass D, O'Kennedy R. Surface Plasmon resonance-based immunoassays: approaches, performance, and applications. Elsevier, Handbook of Immunoassay Technologies, 2018, pp 129-156. https://doi.org/10.1016/B978-0-12-811762-0.00006-2 PMCid:PMC6053827

166. Mohammadzadeh-AsI S, Keshtkar A, Dolatabadi JEN, de la Guardia M. Nanomaterials and phase sensitive based signal Enhancement in surface Plasmon resonance. Biosens Bioelectron, 2018;110:118-31. https://doi.org/ 10.1016/j.bios.2018.03.051 PMid:29604520

167. Hage DS. Development of Immunochromatographic assays for the selective detection of Zika virus or dengue virus serotypes in serum. Clin Chem, 2018;64:991-3. https://doi.org/10.1373/clinchem.2017.282699 PMid:29632126

168. Fletcher SJ, Phillips LW, Milligan AS, Rodda SJ. Toward specific detection of dengue virus serotypes using a novel modular biosensor. Biosens Bioelectron, 2010;26:16961700. https://doi.org/10.1016/j.bios.2010.07.046 PMid: 20692150

169. Xie B-P, Qiu G-H, Hu P-P, Liang Z, Liang Y-M, Sun B, et al. Simultaneous detection of dengue and Zika virus RNA sequences with a three-dimensional cu-based zwitterionic metal-organic framework, comparison of single and synchronous fluorescence analysis. Sensors Actuators B Chem, 2018;254:1133-40. https://doi.org/10.1016/j.snb. 2017.06.085 
170. Alamdari DH, Kostidou E, Paletas K, Sarigianni M, Konstas AG, Karapiperidou A, et al. High sensitivity enzyme-linked immunosorbent assay (ELISA) method for measuring protein carbonyl in samples with low amounts of protein. Free Radic Biol Med, 2005;39:1362-7. https://doi.org/ 10.1016/j.freeradbiomed.2005.06.023 PMid:16257645

171. Kim A, Li C-R, Jin C-F, Lee KW, Lee S-H, Shon K-J, et al. A sensitive and reliable quantification method for bisphenol based on modified competitive ELISA method. Chemosphere, 2007;68:1204-9. https://doi.org/10.1016/ j.chemosphere.2007.01.079 PMid:17382992

172. Thiha A, Ibrahim F. A colorimetric enzyme-linked immunosorbent assay (ELISA) detection platform for a point-of-care dengue detection system on a lab-oncompact disc. Sensors, 2015;15:11431-41. https://doi.org/10.3390/s150511431 PMid:25993517 PMCid:PMC4481904

173. Hosseini S, Ibrahim F, Djordjevic I, Rothan HA, Yusof R, van der Marel C, et al. Synthesis and characterization of methacrylic microspheres for biomolecular recognition: ultrasensitive biosensor for dengue virus detection. Eur Polym J, 2014;60:14-21. https://doi.org/10.1016/ j.eurpolymj.2014.08.010

174. Hosseini S, Azari P, Farahmand E, Gan SN, Rothan HA, Yusof R, et al. Polymethacrylate coated electrospun PHB fibers: an exquisite outlook for fabrication of paper-based biosensors. Biosens Bioelectron, 2015;69:257-64. https://doi.org/10.1016/j.bios.2015.02.034 PMid:25765434

175. Lopez-Jimena B, Bekaert M, Bakheit M, Frischmann S, Patel $P$, Simon-Loriere $E$, et al. Development and validation of four one-step real-time RT-LAMP assays for specific detection of each dengue virus serotype. PLoS Negl Trop Dis, 2018;12:e0006381. https://doi.org/10.1371/ journal.pntd.0006381 PMid:29813062 PMCid:PMC5973574

176. Hasanzadeh M, Karimzadeh A, Sadeghi S, Mokhtarzadeh A, Shadjou N, Jouyban A. Graphene quantum dot as an electrically conductive material toward low potential detection: a new platform for interface science. J Mater Sci-Mater El, 2016;27:6488-95. https://doi.org/10.1007/ s10854-016-4590-6

177. Hasanzadeh M, Baghban HN, Shadjou N, Mokhtarzadeh A. Ultrasensitive electrochemical immunosensing of tumor suppressor protein p53 in unprocessed human plasma and cell lysates using a novel nanocomposite based on poly-cysteine/graphene quantum dots/gold nanoparticle. Int J Biol Macromol, 2018;107:1348-63. https://doi.org/ 10.1016/j.ijbiomac.2017.11.006 PMid:29113888

178. Hassanpour S, Baradaran B, Hejazi M, Hasanzadeh M, Mokhtarzadeh A, de la Guardia M. Recent trends in rapid detection of influenza infections by bio and nanobiosensor. Trends Anal Chem, 2018;98:201-15. https://doi.org/10.1016/j.trac.2017.11.012

179. Oliveira MD, Nogueira ML, Correia MT, Coelho LC, Andrade CA. Detection of dengue virus serotypes on the surface of gold electrodes based on Cratylia mollis lectin affinity. Sensors Actuators B Chem, 2011;155:789-95. https://doi.org/10.1016/j.snb.2011.01.049

180. Dias ACM, Gomes-Filho SL, Silva MM, Dutra RF. A sensor tip based on carbon nanotube-ink printed electrode for the dengue virus NS1 protein. Biosens Bioelectron, 2013;44:216-21.

https://doi.org/10.1016/j.bios.2012.12.033 PMid:23428736
181. Daniels JS, Pourmand N. Label-free impedance biosensors: opportunities and challenges, Electroanalysis (N.Y.N.Y.), 2007;19:1239-57. https://doi.org/10.1002/ elan.200603855 PMid:18176631 PMCid:PMC2174792

182. Bao N, Wang J, Lu C. Recent advances in electric analysis of cells in microfluidic systems. Anal Bioanal Chem, 2008;391:933-42. https://doi.org/10.1007/s00216-0081899-x PMid:18335214

183. Luna DM, Avelino KY, Cordeiro MT, Andrade CA, Oliveira $M D$. Electrochemical immunosensor for dengue virus serotypes based on 4-mercaptobenzoic acid modified gold nanoparticles on self-assembled cysteine monolayers. Sensors Actuators B Chem, 2015;220:565-72. https://doi.org/10.1016/j.snb.2015.05.067

184. Tung Y-T, Wu M-F, Wang G-J, Hsieh S-L. Nanostructured electrochemical biosensor for th0065 detection of the weak binding between the dengue virus and the CLEC5A receptor. Nanomedicine, 2014;10:1335-41. https://doi.org /10.1016/j.nano.2014.03.009 PMid:24674971

185. Senapati S, Slouka Z, Shah SS, Behura SK, Shi Z, Stack MS, et al. An ion-exchange nanomembrane sensor for detection of nucleic acids using a surface charge inversion phenomenon. Biosens Bioelectron, 2014;60:92-100. https://doi.org/10.1016/j.bios.2014.04.008 PMid:24787123 PMCid:PMC4445831

186. Chartuprayoon N, Zhang M, Bosze W, Choa Y-H, Myung NV. One-dimensional nanostructures based bio-detection. Biosens Bioelectron, 2015;63:432-43. https://doi.org/ 10.1016/j.bios.2014.07.043 PMid:25128623

187. Wasik D, Mulchandani A, Yates MV. A heparin functionalized carbon nanotube-based affinity biosensor for dengue virus. Biosens Bioelectron, 2017;91:811-6. https://doi.org/10.1016/j.bios.2017.01.017 PMid:28152487

188. Sri S, Dhand C, Rathee J, Ramakrishna S, Solanki PR. Microfluidic based biosensors as point of care devices for infectious diseases management. Sensor Lett, 2018;16:113. https://doi.org/10.1166/sl.2019.3976

189. Roda A, Michelini E, Zangheri M, Di Fusco M, Calabria D, Simoni P. Smartphone-based biosensors: a critical review and perspectives. Trends Anal Chem, 2016;79:317-25. https://doi.org/10.1016/j.trac.2015.10.019

190. Zhang G, Zhang L, Huang M, Luo Z, Tay G, Lim E, et al. Silicon nanowire biosensor for highly sensitive and rapid detection of Dengue virus. Sensors and Actuators B: Chemical, 2010;146(1):138-44. https://doi.org/10.1016/ j.snb.2010.02.021

191. Kong Y, Thay C, Tin T, Devi S. Rapid detection, serotyping and quantitation of dengue viruses by TaqMan real-time one-step RT-PCR. Journal of Virological Methods, 2006;138(1-2):123-30.

https://doi.org/10.1016/j.jviromet.2006.08.003 PMid: 17000012

192. Murphy B, Whitehead S. Immune Response to Dengue Virus and Prospects for a Vaccine. Annual Review of Immunology, 2011;29(1):587-619. https://doi.org/10.1146/ annurev-immunol-031210-101315 PMid:21219187

193. Questions and Answers on Dengue Vaccines. World Health Organization. Available at: https://www.who.int/immuni zation/research/development/dengue_q_and_a/en/ (Accessed: 8 April 2020).

194. Environmental management. World Health Organization. Available at: https://www.who.int/denguecontrol/control _strategies/environmental_management/en/ (Accessed: 8 April 2020). 
195. Wilder-Smith A, Ooi E, Vasudevan S, Gubler D. Update on Dengue: Epidemiology, Virus Evolution, Antiviral Drugs, and Vaccine Development. Current Infectious Disease Reports, 2010;12(3):157-64. https://doi.org/10.1007/ s11908-010-0102-7 PMid:21308524

196. Rajapakse S, Rodrigo C, Rajapakse A. Treatment of dengue fever. Infection and Drug Resistance, 2012;103. https://doi.org/10.2147/IDR.S22613 PMid:22870039 PMCid:PMC3411372

197. What is dengue and how is it treated?. World Health Organization. 2017. Available at: https://www.who.int/ features/qa/54/en/ (Accessed: 8 April 2020).

198. Future Dengue Fever Treatments | Learn Science at Scitable. Nature.com. Available at: https://www.nature. $\mathrm{com} /$ scitable/topicpage/future-dengue-fever-treatments22404960/ (Accessed: 4 October 2020).

199. Wilder-Smith A. Dengue vaccine development: status and future. Bundesgesundheitsblatt - Gesundheitsforschung Gesundheitsschutz, 2019;63(1):40-4.

https://doi.org/10.1007/s00103-019-03060-3 PMid:31784763 PMCid:PMC7224137

200. Dar L, Ghosh A. Dengue vaccines: Challenges, development, current status and prospects. Indian Journal of Medical Microbiology, 2015;33(1):3. https://doi.org/10.4103/0255-0857.148369 PMid:25559995

201. Thomas S, Yoon I. A review of Dengvaxia ${ }^{\circledR}$ : development to deployment. Human Vaccines \& Immunotherapeutics, 2019;15(10):2295-314.

https://doi.org/10.1080/21645515.2019.1658503

PMid:31589551 PMCid:PMC6816420

202. Dorigatti I, Donnelly C, Laydon D, Small R, Jackson N, Coudeville L, et al. Refined efficacy estimates of the Sanofi Pasteur dengue vaccine CYD-TDV using machine learning. Nature Communications, 2018;9(1).

https://doi.org/10.1038/s41467-018-06006-6

PMid:30194294 PMCid:PMC6128884

203. Sun W, Edelman R, Kanesa-Thasan N, Eckels KH, Putnak $J R$, King AD, et al. Vaccination of human volunteers with monovalent and tetravalent live-attenuated dengue vaccine candidates. Am J Trop Med Hyg, 2003;69:24-31. https://doi.org/10.4269/ajtmh.2003.69.6_suppl.0690024 PMid:14740952

204. Kanesa-Thasan N, Edelman R, Tacket CO, Wasserman SS, Vaughn DW, Coster TS, et al. Phase 1 studies of Walter Reed Army Institute of Research candidate attenuated dengue vaccines: Selection of safe and immunogenic monovalent vaccines. Am J Trop Med Hyg, 2003;69 Suppl 6:17-23. https://doi.org/10.4269/ajtmh.2003.69.17 PMid:14740951

205. Bray M, Lai CJ. Construction of intertypic chimeric dengue viruses by substitution of structural protein genes. Proc Natl Acad Sci U S A, 1991;88:10342-6.

https://doi.org/10.1073/pnas.88.22.10342 PMid:1682924 PMCid:PMC52924

206. Guirakhoo F, Weltzin R, Chambers TJ, Zhang ZX, Soike K, Ratterree $M$, et al. Recombinant chimeric yellow feverdengue type 2 virus is immunogenic and protective in nonhuman primates. J Virol, 2000;74:5477-85. https://doi.org/10.1128/JVI.74.12.5477-5485.2000 PMid:10823852 PMCid:PMC112032

207. Osorio JE, Huang CY, Kinney RM, Stinchcomb DT. Development of DENVax: A chimeric dengue-2 PDK-53based tetravalent vaccine for protection against dengue fever. Vaccine, 2011;29:7251-60. https://doi.org/10.1016/ j.vaccine.2011.07.020 PMid:21777638 PMCid:PMC4592106
208. World Health Organization, Geneva, 2013. Dengue vaccine candidates in clinical development. Available at: http:// www.who.int/immunization/sage/meetings/2013/april/1 _. Dengue_SAGE_Apr2013_Vaccine_Candidates.pdf

209. Whitehead SS, Falgout B, Hanley KA, Blaney Jr JE Jr, Markoff L, Murphy BR. A live, attenuated dengue virus type 1 vaccine candidate with a 30-nucleotide deletion in the $3^{\prime}$ untranslated region is highly attenuated and immunogenic in monkeys. J Virol, 2003;77:1653-7. https://doi.org/10.1128/JVI.77.2.1653-1657.2003 PMid:12502885 PMCid:PMC140839

210. Men R, Bray M, Clark D, Chanock RM, Lai CJ. Dengue type 4 virus mutants containing deletions in the $3^{\prime}$ noncoding region of the RNA genome: Analysis of growth restriction in cell culture and altered viremia pattern and immunogenicity in rhesus monkeys. J Virol, 1996;70:39307. $\quad$ https://doi.org/10.1128/JVI.70.6.3930-3937.1996 PMid:8648730 PMCid:PMC190271

211. Putnak R, Barvir DA, Burrous JM, Dubois DR, D'Andrea VM, Hoke $\mathrm{CH}$, et al. Development of a purified, inactivated, dengue-2 virus vaccine prototype in Vero cells: Immunogenicity and protection in mice and rhesus monkeys. J Infect Dis, 1996;174:1176-84. https://doi.org/10.1093/infdis/174.6.1176 PMid:8940206

212. Clements DE, Coller BA, Lieberman MM, Ogata S, Wang G, Harada KE, et al. Development of a recombinant tetravalent dengue virus vaccine: Immunogenicity and efficacy studies in mice and monkeys. Vaccine 2010;28:2705-15.

https://doi.org/10.1016/j.vaccine.2010.01.022 PMid:20097152 PMCid:PMC2837772

213. Danko JR, Beckett CG, Porter KR. Development of dengue DNA vaccines. Vaccine, 2011;29:7261-6. https://doi.org/ 10.1016/j.vaccine.2011.07.019 PMid:21777640

214. Stages of vaccine development | European Vaccine Initiative. Eu Vaccine.eu. [cited 11 April 2020]. Available at: http://www.euvaccine.eu/vaccines-diseases/vaccines/ stages-development (Accessed: 11 April 2020).

215. MODULE 1 - Pre-licensure vaccine safety - WHO Vaccine Safety Basics. Vaccine-safety-training.org. Available at: https://vaccine-safety-training.org/pre-licensure-vaccinesafety.html (Accessed: 11 April 2020).

216. Mustafa M, Rastogi V, Jain S, Gupta V. Discovery of fifth serotype of dengue virus (DENV-5): A new public health dilemma in dengue control. Medical Journal Armed Forces India, 2015;71(1):67-70. https://doi.org/10.1016/ j.mjafi.2014.09.011 PMid:25609867 PMCid:PMC4297835

217. Cegolon L, Heymann W, Lange J. Comment on: Definitive tests for dengue fever: when and which should I use?. Singapore Medical Journal, 2018;59(3):165.

https://doi.org/10.11622/smedj.2018032 PMid:29568854 PMCid:PMC5861342

218. Takeda to invest more than 100 Million Euros in Dengue Vaccine Manufacturing plant in Germany [Internet]. Takeda.com. 2016. Available at: https://www.takeda.com/ newsroom/newsreleases/2016/Takeda-to-invest-more-th an-100-Million-Euros-in-Dengue/?fbclid=IwAR2FZsIYM9if dLNkgK-X0DhDP3sQABToyrcdlFvw4HoaSzZvt8rJwzuTBfg (Accessed: 13 April 2020). 
219. The WMP welcomes AUD\$50m funding from the Gates Foundation and Wellcome Trust [Internet]. Eliminate Dengue.com. 2018. Available at: http://www.eliminate dengue.com/progress/index/view/news/1088?fbclid=IwA R02TUU0DyQxtC9gGLs906BQcgXYAARXeKL-

EL4lkYFyBwoLZGye1oowRNI (Accessed: 13 April 2020).

220. GHIT Fund Announces New Investments in Vaccines for Dengue and Leishmaniasis, and Drug Screening for Malaria and Tuberculosis. Prnewswire.com. 2018. Available at: https://www.prnewswire.com/news-releases/ghit-fundannounces-new-investments-in-vaccines-for-dengueand-leishmaniasis-and-drug-screening-for-malaria-andtuberculosis-300764602.html?fbclid=IwAR2yPukXhCDX yi8Hq3gehIMVAIWQBf-UFL2mnF0gWXA4VziaXNU2G1EhP0 (Accessed: 13 April 2020).

221. BNDES approves R\$97.2 million investment in dengue vaccine. Brazil. 2017. Available at: http://www.brazil. gov.br/about-brazil/news/2017/01/bndes-approves-r-972-million-investment-in-dengue-vaccine?fbclid=IwAR1gc pErbINR1Pha8uV35HRwrlthwnYnFHAV6DEBTaMaRenYJy u Jzwjli5M (Accessed: 13 April 2020).

222. People's initial immune response to dengue fever analyzed. ScienceDaily. 2019. Available at: https://www. sciencedaily.com/releases/2019/08/190829081359.htm?f bclid=IwAR2URohGky6kzKo0dX4l9xAEQ_rlMZ_HDP04awy pYNv_iFgpeTpp8f4WdRA (Accessed: 13 April 2020).
223. Mosquitoes engineered to repel dengue virus. ScienceDaily. 2020. Available at: https://www.sciencedaily .com/releases/2020/01/200116141710.htm?fbclid=IwARO ecqZaFfFzR4Gw2anZgHEilkCXOGDxDk6o1k7jNJ4IYISdUh 8Rv_FyaVc (Accessed: 13 April 2020).

224. Dengue virus becoming resistant to vaccines and therapeutics due to mutations in specific protein. ScienceDaily. 2019. Available at: https://www.sciencedaily .com/releases/2019/09/190920102844.htm?fbclid=IwAR1 O_AUmH1Ez1zDelurvBKUzUiyEkzglemafbcpvKoeliWXfkad OyTwZVPO (Accessed: 13 April 2020).

225. Xu Z, Bambrick H, Frentiu F, Devine G, Yakob L, Williams G, et al. Projecting the future of dengue under climate change scenarios: Progress, uncertainties and research needs. PLOS Neglected Tropical Diseases, 2020;14(3):e0008118. https://doi.org/10.1371/journal.pntd.0008118 PMid:32119666 PMCid:PMC7067491

226. Current Dengue Fever Research | Learn Science at Scitable. Nature.com. Available at: https://www.nature.com/scit able/topicpage/current-dengue-fever-research-22404441 /?fbclid=IwAR001C8bv0d8ksocMTN4q0WzMIAZoFxJF7qo Qi620Q7pUE1024j93vP3GnU (Accessed: 13 April 2020).

227. Murray N, Quam M, Wilder-Smith A. Epidemiology of dengue: past, present and future prospects. Clinical Epidemiology, 2013;299. https://doi.org/10.2147/ CLEP.S34440 PMid:23990732 PMCid:PMC3753061 